\title{
Design, Synthesis of Analgesics and Anticancer of Some New Derivatives of Benzimidazole
}

\author{
Helmy M. Sakr, Rezk R. Ayyad, Kazem Mahmoud, Ahmed M. Mansour, Ahmed. G Ahmed* \\ ${ }^{1}$ Pharmaceutical Medicinal Chemistry Department, Faculty of Pharmacy Al-Azhar University, Cairo, Egypt \\ ${ }^{2}$ Pharmaceutical Chemistry Department, Faculty of Pharmacy, Egyptian Russian University, Cairo, Egypt \\ ${ }^{3}$ Pharmacology and Toxicology Department, Faculty of Pharmacy Al-Azhar University, Cairo, Egypt \\ ${ }^{4}$ Ministry of Interior, Sector of Medical Services, Cairo, Egypt \\ Email: *smart_pharma@msn.com
}

How to cite this paper: Sakr, H.M., Ayyad, R.R., Mahmoud, K., Mansour, A.M. and Ahmed, A.G. (2021) Design, Synthesis of Analgesics and Anticancer of Some New Derivatives of Benzimidazole. International Journal of Organic Chemistry, 11, 144-169. https://doi.org/10.4236/ijoc.2021.113011

Received: April 14, 2021

Accepted: September 27, 2021

Published: September 30, 2021

Copyright (c) 2021 by author(s) and Scientific Research Publishing Inc. This work is licensed under the Creative Commons Attribution International License (CC BY 4.0).

http://creativecommons.org/licenses/by/4.0/

\begin{abstract}
This work, contains some new compounds from benzimidazole derivatives, which are synthesized by condensation of Orthophenylene diamine and Carbon disulfide resulting in 2-Mercapto-benzimidazole which is treated by alcoholic potassium hydroxide forming potassium salt of 2-mercaptobenzimidazole which reacts with different substances (alkyl chloroacetates, chloroacetic chloride, alkyl halides) also the ethoxy carbonyl methyl thiobenzimidazole reacts with different amines. In addition to chloromethyl benzimidazole which resulted from the reaction between orthophenylene diamine and chloroacetic acid, which reacted with different amines. The synthesized compound tested as analgesics and anticancer activity the new derivatives revealed moderate, strong and very strong analgesics and moderate and strong anticancer activity.
\end{abstract}

\section{Keywords}

Benzimidazole, Analgesics and Anticancer

\section{Introduction}

The chemical structure of heterocyclic compounds especially the structures which have benzo diazine and benzo diazole (phthalazine, Quinoxaline, Quinazoline and benzimidazole) have many biological activities antibacterial, anticonvulsant, oral hypoglycemics, anticancer, anthelmintics, antiprotozoal, anti-inflammatory, analgesics, antioxidants, growth regulators, and other biological uses. So, we choose the benzimidazoles which are promising nucleus. It has an analgesic activity like diclofenac and also has anticancer activity as doxirubsin i.e., six membered ring 
fused with five membered ring containing two nitrogen like some compounds of anticancer, so we synthesized the following structure [1]-[23].
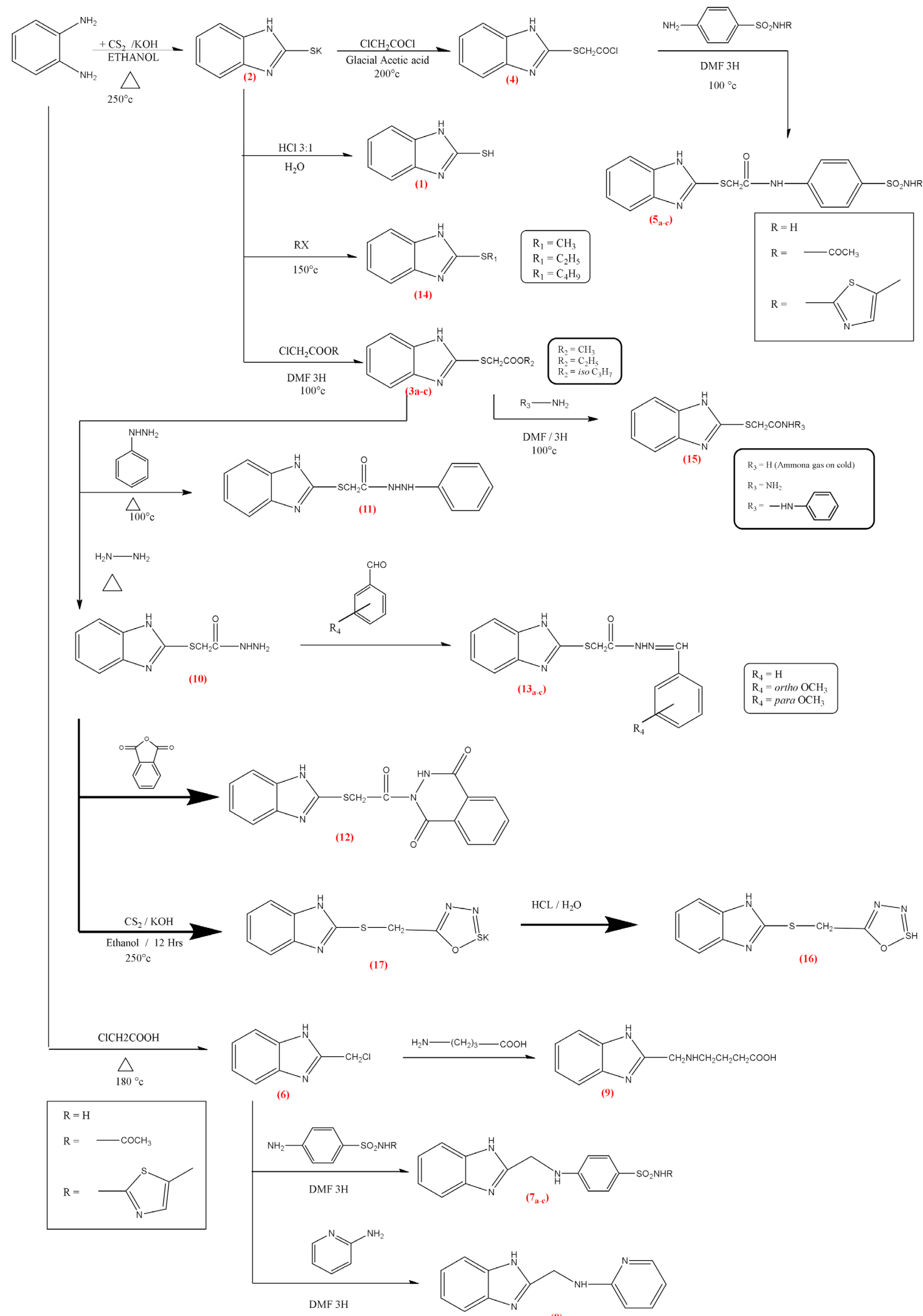


\section{Chemistry and Experimental}

\subsection{H-benzo[d]imidazole-2-thiol (1)}

Weight $10.8 \mathrm{~g}(0.1 \mathrm{~mol})$ of orthophenylene diamine (OPD) and $10 \mathrm{ml}$ of carbon disulfide were refluxed in ethanol for 35 hours. Then allow to cool, the formed precipitate was collected. Crystalize from ethanol as reported. M.P: $300^{\circ} \mathrm{C}-304^{\circ} \mathrm{C}$.<smiles>Sc1nc2ccccc2[nH]1</smiles>

\subsection{Potassium 1H-benzo[d]imidazole-2-thiolate (2)}

We take $1.5 \mathrm{gm}(0.01 \mathrm{~mol})$ of 2-mercaptobenzimidazole (1) and react with alcoholic potassium hydroxide $(\mathrm{KOH})(0.56 \mathrm{gm} 0.01 \mathrm{~mol})$ refluxed with ethanol for 30 min with stirring, the yield is collected and dried, crystalized from ethanol the yield was $95 \%$ ( $1.786 \mathrm{gm})$ melting point $>300$.<smiles>[Ge]c1nc2ccccc2[nH]1</smiles>

\subsection{Alkyl 2-((1H-benzo[d]imidazol-2-yl) Thio) Acetate (3a-c)}<smiles>O=C(O)CSc1nc2ccccc2[nH]1</smiles>

To $1.88 \mathrm{gm}(0.01 \mathrm{~mol})$ of potassium salt of $1 \mathrm{H}$-benzo[d]imidazole-2-thiolate we add $0.01 \mathrm{~mol}$ of the alkyl chloroacetate, then refluxed in DMF (Dimethylformamide) on water bath for 6 hours then pour on crushed ice forming the precipitate filter, dried and crystallized from ethanol.

The compound $3 \mathrm{a} \mathrm{R}=\mathrm{CH}_{3}$ yield, $60 \%$ (1.332 gm), Melting point: $181^{\circ} \mathrm{C}$ $183^{\circ} \mathrm{C}$, Molecular formula $\mathrm{C}_{10} \mathrm{H}_{10} \mathrm{~N}_{2} \mathrm{O}_{2} \mathrm{~S}$ (227) and the Microanalysis (CHN) the Calc. C: 54.10, H: 4.5 and $\mathrm{N} 12.92$ and the Found: C: 53.78, H: 4.41 and N: 13.01.

The compound $3 \mathrm{~b} \mathrm{R}=\mathrm{C}_{2} \mathrm{H}_{5}$ yield, $95 \%$ (2.242 gm), Melting point: $123^{\circ} \mathrm{C}-$ $125^{\circ} \mathrm{C}$, Molecular formula $\mathrm{C}_{11} \mathrm{H}_{12} \mathrm{~N}_{2} \mathrm{O}_{2} \mathrm{~S}$ (236) and the Microanalysis (CHN) the Calc. C: 55.6, H: 5.1 and N 11.86 and the Found: C: 56.14, H: 5.25 and N 12.14.

IR $\left(\mathrm{cm}^{-1}\right) 1710$ (COOEt) and $3100 \mathrm{NH}$

1HNMR (ppm): 1 ( $\mathrm{S}, 3 \mathrm{H}, \mathrm{CH}_{3}, 4.1\left(\mathrm{~d}, 2 \mathrm{H} \mathrm{CH}_{2}\right)$ 7.1-7.4 (m, aromatic protons) and 12.4 ( $\mathrm{S}, \mathrm{H}, \mathrm{NH}$ of ring).

The compound $3 \mathrm{c} \mathrm{R}=$ iso $\mathrm{C}_{3} \mathrm{H}_{7}$ yield, $50 \%$ (1.25 gm), Melting point: $202^{\circ} \mathrm{C}$ $204^{\circ} \mathrm{C}$, Molecular formula $\mathrm{C}_{12} \mathrm{H}_{14} \mathrm{~N}_{2} \mathrm{O}_{2} \mathrm{~S}$ (250) and the Microanalysis (CHN) the Calc. C: 57.6, H: 5.6 and N 11.2 and the Found: C: 57.89, H: 5.83 and N 11.46. 
IR $\left(\mathrm{cm}^{-1}\right): 1690\left(\mathrm{COOCH}\left(\mathrm{CH}_{3}\right)_{2}\right)$ and $3111 \mathrm{NH}$

1HNMR (ppm): 1.19 (m, -CH- $\left(\mathrm{CH}_{3}\right)_{2}, 4.15-\mathrm{SCH}_{2}, 4.93 \mathrm{CH}\left(\mathrm{CH}_{3}\right)_{2} 7.13-8$ (m, aromatic protons) and 12.54 (s, $\mathrm{NH}$ of the ring).

\subsection{2-((1H-benzo[d]imidazol-2-yl) Thio) Acetyl Chloride (4)}<smiles>O=C(Cl)c1nc2ccccc2[nH]1</smiles>

To $1.88 \mathrm{gm}(0.01 \mathrm{~mol})$ of potassium salt $(2)$ react with $(1.12 \mathrm{ml})(0.01 \mathrm{~mol})$ of chloroacetyl chloride in Dimethyl formamide (DMF), refluxed on water bath for 3 hours, pour into crushed ice the precipitate of compound (4) is formed., Allow the compound to dry and crystallized from glacial acetic acid.

Yield $90 \%$ (2.03 gm), Melting point $98^{\circ} \mathrm{C}-99^{\circ} \mathrm{C}$, Molecular weight: 226, Molecular formula $\mathrm{C}_{9} \mathrm{H}_{7} \mathrm{~N}_{2} \mathrm{OSCl}$.

\subsection{2-((1H-benzo[d]imidazol-2-yl)thio)-N-(4sulfamoylphenyl) acetamide ( 5 a), 2-((1H-benzo[d]imidazol-2-yl)thio)-N-(4- ( $\mathrm{N}$-acetyl sulfamoyl) phenyl) acetamide $\left(5_{b}\right)$, 2-((1H-benzo[d]imidazol-2-yl)thio)-N-(4-(N-(thiazol-2-yl) sulfamoyl)phenyl)acetamide (5c)}<smiles>[R2]NS(=O)(=O)c1ccc(NC=O)cc1</smiles>

The compound 2-((1H-benzo[d]imidazol-2-yl) thio) acetyl chloride (4) reacts with different derivatives of sulfonamide $(1.72 \mathrm{gm} 0.01 \mathrm{~mol})$ and the $(2.14 \mathrm{gm}$ $0.01 \mathrm{~mol}$ ) of corresponding sulfa refluxed in DMF on water bath for 4 hours then poured on crushed ice forming compounds (5a-c).

The compound $5 \mathrm{a} \mathrm{R}_{2}=\mathrm{H}$ yield, $90 \%$ (3.26 gm), Melting point: $278^{\circ} \mathrm{C}-279^{\circ} \mathrm{C}$, Molecular formula $\mathrm{C}_{15} \mathrm{H}_{14} \mathrm{~N}_{4} \mathrm{O}_{3} \mathrm{~S}_{2}$ (362) and the Microanalysis (CHN) the Calc. C: 49.7, H: 3.89 and N 15.46 and the Found: C: 49.31, H: 4.92 and N 15.31.

The compound $5 \mathrm{~b} \mathrm{R}=\mathrm{COCH}_{3}$ yield, $82 \%$ (3.31 gm), Melting point: $191^{\circ} \mathrm{C}-$ $193^{\circ} \mathrm{C}$, Molecular formula $\mathrm{C}_{17} \mathrm{H}_{16} \mathrm{~N}_{4} \mathrm{O}_{4} \mathrm{~S}_{2}$ (404) and the Microanalysis (CHN) the Calc. C: $50.48, \mathrm{H}: 3.99$ and N 13.85 and the Found: C: 50.47, H: 4.12 and N 14.21 .

The compound $5 \mathrm{C} \mathrm{R}_{2}=$<smiles>Cc1cncs1</smiles>
yield, 50\% (2.295 gm), Melting point:

$231^{\circ} \mathrm{C}-233^{\circ} \mathrm{C}$, Molecular formula $\mathrm{C}_{19} \mathrm{H}_{17} \mathrm{~N}_{5} \mathrm{O}_{3} \mathrm{~S}_{3}$ (459) and the Microanalysis (CHN) the Calc. C: 49.66, H: 3.75 and N 12.25 and the Found: C: 49.85, H: 3.52 and $\mathrm{N} 15.04$.

${ }^{1} \mathrm{HNMR}(\mathrm{ppm}) 1.2\left(\mathrm{~S}, 3 \mathrm{H} \mathrm{CH}_{3}\right.$ of thiazole ring), 4,91 (d,2 $\left.\mathrm{H} \mathrm{CH}_{2}\right)-\mathrm{S} 7.13$ - 7.72 
(m,8H of aromatic protons) and 10.27 (S, NH of benzimidazole ring respectively).

\subsection{2-(Chloromethyl)-1H-benzo[d]imidazole (6)}<smiles>ClCc1nc2ccccc2[nH]1</smiles>

The orthophenylene diamine (1.08 gm, $0.01 \mathrm{~mol})$ with chloroacetic acid (0.94 gm $0.01 \mathrm{~mol}$ ) in ethanol, reflux for 4 hours the compound (6) is formed allow to cool and crystallized from ethanol, Yield 95\% (1.577 gm), Melting point 181 183, Molecular weight (166) Molecular formula: $\mathrm{C}_{8} \mathrm{H}_{7} \mathrm{~N}_{2} \mathrm{Cl}$.

\subsection{4-(((1H-benzo[d]imidazol-2-yl)methyl)amino)benzenesul-} fonamide (7 a), $\mathrm{N}$-((4-c((1H-benzo[d]imidazol-2-yl)methyl)amino)-phenyl)sulfonyl)acetamide (7b), 4-(((1H-benzo[d]imidazol-2-yl)methyl)amino)- $\mathrm{N}$ (5-methylthiazol-2-yl) benzenesulfonamide (7c)

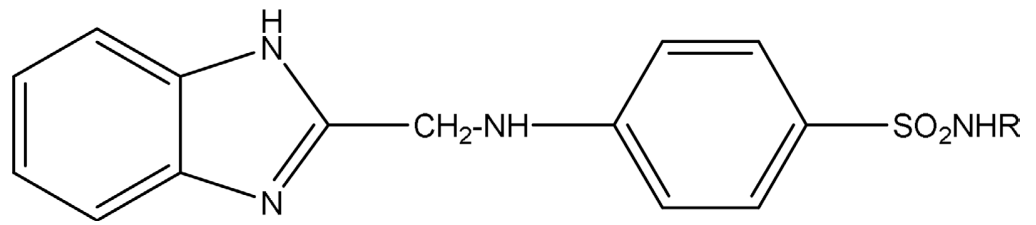

The compound 2-(Chloromethyl)-1H-benzo[d]imidazole (6) (1.66 gm $0.01 \mathrm{~mol}$ ) reacts with the corresponding sulfa drug (sulfanilamide, sulfacetamide and sulfamethazole) respectively $(0.01 \mathrm{~mol})$ in DMF on water bath for 4 hours and pour them on crushed ice to obtain the compound (7a-c).

The compound 7a $\mathrm{R}=\mathrm{H}$ yield, $75 \%$ (226.5 gm), Melting point: $231^{\circ} \mathrm{C}-233^{\circ} \mathrm{C}$, Molecular formula $\mathrm{C}_{14} \mathrm{H}_{14} \mathrm{~N}_{4} \mathrm{O}_{2} \mathrm{~S}(302)$ and the Microanalysis $(\mathrm{CHN})$ the Calc. C: 55.62, H: 4.67 and $\mathrm{N} 18.53$ and the Found: C: 55.44, H: 4.91 and $\mathrm{N} 18.67$.

The compound $7 \mathrm{~b} \mathrm{R}=\mathrm{COOCH}_{3}$ yield, $80 \%$ (323.2 gm), Melting point: $250^{\circ} \mathrm{C}$ $252^{\circ} \mathrm{C}$, Molecular formula $\mathrm{C}_{16} \mathrm{H}_{16} \mathrm{~N}_{4} \mathrm{O}_{3} \mathrm{~S}(404)$ and the Microanalysis (CHN) the Calc. C: 55.80, H: 4.68 and N 16.27 and the Found: C: 56.02, H:4.91 and N 16.54.

The compound $7 \mathrm{c} \mathrm{R}=$<smiles>Cc1cncs1</smiles>
yield, $45 \%$ (1.8 gm), Melting point: $281^{\circ} \mathrm{C}$

$283^{\circ} \mathrm{C}$, Molecular formula $\mathrm{C}_{18} \mathrm{H}_{17} \mathrm{~N}_{5} \mathrm{O}_{2} \mathrm{~S}_{2}$ (459) and the Microanalysis $(\mathrm{CHN})$ the Calc. C: 54.12, H: 4.29 and N 17.53 and the Found: C: 54.32, H: 4.43 and N 17.80.

\subsection{N-((1H-benzo[d]imidazol-2-yl) Methyl) Pyridin-2-Amine (8)}

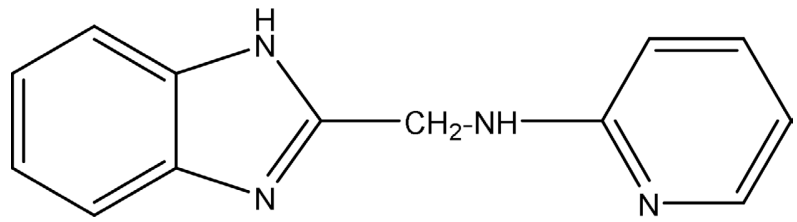


The compound 2-(Chloromethyl)-1H-benzo[d]imidazole (6) (1.66 gm (0.01 mol) react with 2-aminopyridine $(0.095 \mathrm{gm} 0.01 \mathrm{~mol})$ and refluxed on DMF on water bath for 4 hours then pour into crushed ice, filtrate dried and crystallized from ethanol Yield $60 \%(1.34 \mathrm{gm})$, Melting point $216^{\circ} \mathrm{C}-217^{\circ} \mathrm{C}$ Molecular weight: 224, Molecular formula $\mathrm{C}_{13} \mathrm{H}_{13} \mathrm{~N}_{4}$ the Microanalysis (CHN) the Calc. C: 69.52, H: 5.39 and $\mathrm{N} 27.94$ and the Found: C: 69.87, H: 5.18 and N 25.21.

IR $\left(\mathrm{cm}^{-1}\right): 3250 \mathrm{~cm}^{-1}(\mathrm{NH})$ and $3100 \mathrm{~cm}^{-1}$ of aromatic ring

${ }^{1} \mathrm{HNMR}(\mathrm{ppm}): 4.3\left(\mathrm{~d}, 2 \mathrm{H} \mathrm{CH}_{2}\right), 6.81-7.9(\mathrm{~m} 8 \mathrm{H}$, of aromatic protons of pyridine and benzene of benzimidazole) and $12.2(\mathrm{~s}, \mathrm{H} \mathrm{NH})$ of the benzimidazole ring.

\subsection{4-(((1H-benzo[d]imidazol-2-yl) Methyl) Amino) Butanoic Acid (9)}

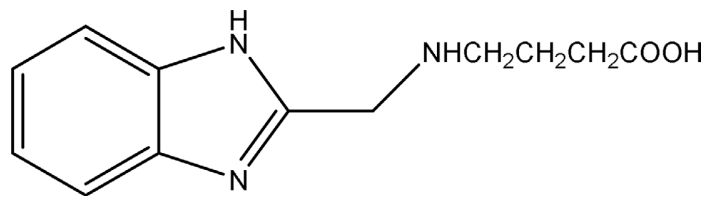

The compound 2-(Chloromethyl)-1H-benzo[d]imidazole (6) (1.66 gm $0.01 \mathrm{~mol})$ reacts with $(0.89 \mathrm{gm} 0.01 \mathrm{~mol})$ of 4 amino butanoic acid refluxed in DMF on water bath for 3 hours, then pour on crushed ice, filtered, dried and crystallized from ethanol.

Yield 95\% (2.21 gm), Molecular weight 233, Molecular formula $\mathrm{C}_{12} \mathrm{H}_{15} \mathrm{~N}_{3} \mathrm{O}_{3}$ Melting pint: $141^{\circ} \mathrm{C}-143^{\circ} \mathrm{C}$ and) and the Microanalysis (CHN) the Calc. C: 61.79, H: 6.48 and N 18.01 and the Found: C: 62.09, H: 6.56 and N 17.95.

IR $\left(\mathrm{cm}^{-1}\right): 1565 \mathrm{~cm}^{-1}(\mathrm{COOH})$ and $3245 \mathrm{~cm}^{-1}$ of NH and $3130 \mathrm{~cm}^{-1}$ for benzene ring.

${ }^{1} \mathrm{HNMR}$ (ppm): (1.5 - $2.3\left(\mathrm{~m},\left(\mathrm{CH}_{2}\right)_{3}, 4.3 \mathrm{CH}_{2}-\mathrm{NH}, 4.7 \mathrm{NH}-\mathrm{CH}_{2}, 7.1-7.5(\mathrm{~m} 4\right.$ $\mathrm{H}$ of aromatic ring, $10.5 \mathrm{~s}, \mathrm{H} \mathrm{COOH}$ and $12.3 \mathrm{~s}, \mathrm{H}$ of NH of the ring.

\subsection{2-((1H-benzo[d]imidazol-2-yl) Thio) Acetohydrazide (10)}<smiles>NNC(=O)c1nc2ccccc2[nH]1</smiles>

The compound-((1H-benzo[d]imidazol-2-yl) thio) acetyl chloride (6) (2.36 gm $0.01 \mathrm{~mol})$ reacts with Hydrazine hydrate $(0.32 \mathrm{gm})$ excess. the reaction heated over heater for $30 \mathrm{~min}$ and left the compound to cool, filtered, dried and crystallized from ethanol.

Yield: $95 \%$ (2.11 gm), Melting point: $246^{\circ} \mathrm{C}-248^{\circ} \mathrm{C}$ Molecular weight: 222, Molecular formula $\mathrm{C}_{9} \mathrm{H}_{10} \mathrm{~N}_{4} \mathrm{OS}$ and the Microanalysis (CHN) the Calc. C: 48.63 , H: 4.54 and N: 25.21 and the Found: C: 48.42, H: 4.75 and N 24.75.

IR $\left(\mathrm{cm}^{-1}\right): 1565 \mathrm{~cm}^{-1} \mathrm{CO}$ and 3241 of $\mathrm{NH}, 3335 \mathrm{NH}_{2}$ and 3169 for benzene ring. 
1HNMR (ppm): 4.3 (d,2H NH2), 9.1 (s, H, NH-NH2) 3.6 (d,2H, CH2) 7.1 $7.5(\mathrm{~m}, 4 \mathrm{H}$ of aromatic protons) and $12.2(\mathrm{~s}, \mathrm{H}, \mathrm{NH}$ of the ring).

\subsection{2-((1H-benzo[d]imidazol-2-yl)} thio)-N'-phenylacetohydrazide (11)

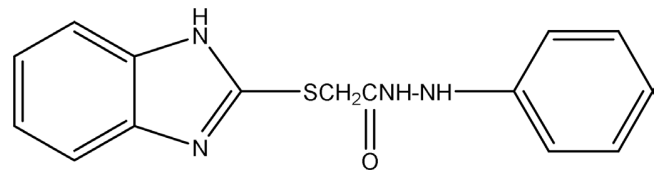

The compound (6) (2.36 gm $0.01 \mathrm{~mol}$ ) reacts with phenyl Hydrazine (1.08 gm $0.01 \mathrm{~mol}$ ) respectively refluxed in ethanol for 3 hours. left the compound to cool, filtered, dried and crystallized from ethanol. Yield: 75\% (2.23 gm), Melting point: $288^{\circ} \mathrm{C}-290^{\circ} \mathrm{C}$ Molecular weight: 298, Molecular formula $\mathrm{C}_{15} \mathrm{H}_{14} \mathrm{~N}_{4} \mathrm{OS}$ $\mathrm{C}_{9} \mathrm{H}_{10} \mathrm{~N}_{4} \mathrm{OS}$ and the Microanalysis (CHN) the Calc. C: $60.36, \mathrm{H}: 4.73$ and $\mathrm{N} 18.78$ and the Found: C: $60.23, \mathrm{H}: 4.98$ and $\mathrm{N} 18.96$.

IR $\left(\mathrm{cm}^{-1}\right): 1695 \mathrm{~cm}^{-1} \mathrm{CO}$ and 3245 of $\mathrm{NH}$, and 3145 for benzene ring.

${ }^{1} \mathrm{HNMR}(\mathrm{ppm}): 3.90\left(\mathrm{~d}, 2 \mathrm{H} \mathrm{CH}_{2}\right), 5.8$ (s, H, C=ONH-NH),8.4 (S,1H-NH aromatic) $6.5-7.8$ (m,9H of aromatic protons) and 12.1 (s,1H of $\mathrm{NH}$ of the ring).

\subsection{2 -(2-((1H-benzo[d]imidazol-2-yl) thio) acetyl)-2,3-dihydrophthalazine-1,4-dione (12)}

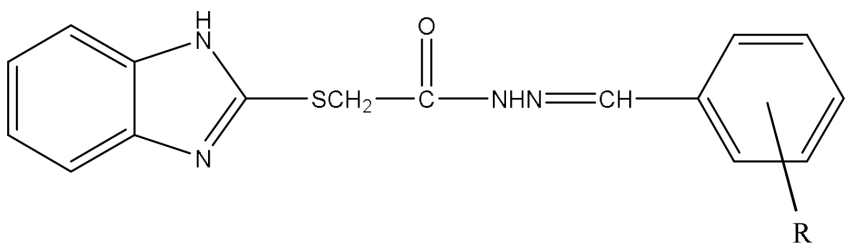

To conical flask weight $(2.22 \mathrm{gm} 0.01 \mathrm{~mol})$ of compound 2-((1H-benzo[d]- imidazol-2-yl) thio) acetohydrazide (10) (2- add (1.48 gm $0.01 \mathrm{~mol}$ ) of phthalic anhydride and refluxed in ethanol for 8 hours then left it to cool, filtered, dried and crystallized from ethanol.

Yield 95\% (3.34 gm), Melting point: $272^{\circ} \mathrm{C}-274^{\circ} \mathrm{C}$, Molecular weight: 352, Molecular formula: $\mathrm{C}_{14} \mathrm{H}_{12} \mathrm{~N}_{4} \mathrm{O}_{3} \mathrm{~S}$ and the Microanalysis (CHN) the Calc. C: 57.95, H: 3.43 and $\mathrm{N} 15.9$ and the Found: C: 57.89, H: 3.46 and $\mathrm{N} 15.78$.

${ }^{1} \mathrm{HNMR}(\mathrm{ppm}): 3.90\left(\mathrm{~d}, 2 \mathrm{H} \mathrm{CH}_{2}\right), 7.2-8(\mathrm{~m}, 8 \mathrm{H}$ of aromatic protons, $11.9(\mathrm{~s}, \mathrm{H}$, $\mathrm{NH}$ of phthalazine ring) and $12.1(\mathrm{~s}, \mathrm{H}, \mathrm{NH}$ of benzimidazole).

\subsection{3. (Z)-2-((1H-benzo[d]imidazol-2-yl)} thio)-N'-benzylideneacetohydrazide (13a)

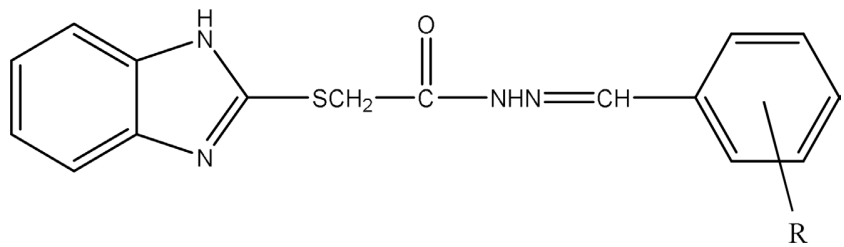


- (Z)-2-((1H-benzo[d]imidazol-2-yl) thio)-N'-(4-methoxybenzylidene) acetohydrazide (13b)

- (Z)-2-((1H-benzo[d]imidazol-2-yl) thio)-N'-(2-methoxybenzylidene) acetohydrazide (13c)

Weight (2.22 gm $0.01 \mathrm{~mol})$ of compound 2-((1H-benzo[d]imidazol-2-yl) thio) acetohydrazide (10) in conical flask. add the corresponding weight of aromatic aldehyde $(0.01 \mathrm{~mol})$ and refluxed respectively in glacial acetic acid for 8 hours. pour on water, filtered, dried and crystallized from glacial acetic acid.

The compound $13 \mathrm{a} \mathrm{R}=\mathrm{H}$ yield, $90 \%(2.79 \mathrm{gm})$, Melting point: $262^{\circ} \mathrm{C}-264^{\circ} \mathrm{C}$, Molecular formula $\mathrm{C}_{16} \mathrm{H}_{14} \mathrm{~N}_{4} \mathrm{OS}$ (310) and the Microanalysis (CHN) the Calc. C: 61.92, H: 4.55 and N 18.05 and the Found: C: 62.17, H: 4.28 and N 18.23.

IR $\left(\mathrm{cm}^{-1}\right): 1695-\mathrm{CO}, 3235-\mathrm{NH}, 3335 \mathrm{NH}$ and 3110 for aromatic

${ }^{1} \mathrm{HNMR}$ (ppm): 4.2(d, $\left.2 \mathrm{H}, \mathrm{CH}_{2}\right) 8.41$ (s, $\mathrm{H}, \mathrm{CH}$ aromatic) $7.2-8$ (m, $8 \mathrm{H}$, aromatic protons) and 12.1 (s, $\mathrm{H}, \mathrm{NH}$ of the ring).

The compound 13b R=P-methoxy benzaldehyde yield, 60\% (2.04 gm), Melting point: $287^{\circ} \mathrm{C}-298^{\circ} \mathrm{C}$, Molecular formula $\mathrm{C}_{17} \mathrm{H}_{16} \mathrm{~N}_{4} \mathrm{O}_{2} \mathrm{~S}$ (340) and the Microanalysis (CHN) the Calc. C: 60, H: 4.71 and N 16.5 and the Found: C: 60.17, H: 4.28 and $\mathrm{N} 16.23$.

IR $\left(\mathrm{cm}^{-1}\right): 1690$ (-CO-), $3335 \mathrm{NH}$ and 3115 of aromatic

${ }^{1} \mathrm{HNMR}(\mathrm{ppm}): 2.4\left(\mathrm{~s}, 3 \mathrm{H}, \mathrm{CH}_{3}\right), 4.1\left(\mathrm{~d}, 2 \mathrm{H}, \mathrm{CH}_{2}\right), 8.3(\mathrm{~s}, \mathrm{H}, \mathrm{CH}) 7.3-8(\mathrm{~m}, 8 \mathrm{H}$ of aromatic ring) and $12.2(\mathrm{~s}, 1 \mathrm{H}, \mathrm{NH}$ of the ring).

The compound $13 \mathrm{c} \mathrm{R}=\mathrm{P}$-methoxy yield, $50 \%$ (1.7 gm), Melting point: $255^{\circ} \mathrm{C}$ $257^{\circ} \mathrm{C}$, Molecular formula $\mathrm{C}_{17} \mathrm{H}_{16} \mathrm{~N}_{4} \mathrm{O}_{2} \mathrm{~S}$ (340) and the Microanalysis ( $\mathrm{CHN}$ ) the Calc. C: 60, H: 4.71 and N 16.23 and the Found: C: 59.54, H: 5.15 and N 16.4.

IR $\left(\mathrm{cm}^{-1}\right)$ : 1685 -CO-, $3340-\mathrm{NH}-, 3110$ for aromatic

${ }^{1} \mathrm{HNMR}(\mathrm{ppm}): 3.7\left(\mathrm{~s}, 3 \mathrm{H}, \mathrm{CH}_{3}\right) 4.2\left(\mathrm{~d}, 2 \mathrm{H}, \mathrm{CH}_{2}\right)$ and $8.3(\mathrm{~s}, 1 \mathrm{H}$ of aromatic ring) $7.3-8(\mathrm{~m}, 8 \mathrm{H}$ aromatic protons) and $12.1(\mathrm{~s}, 1 \mathrm{H}, \mathrm{NH}$ of the ring $)$.

\subsection{2-(Alkylthio)-1H-benzo[d]imidazole (14a-c)}
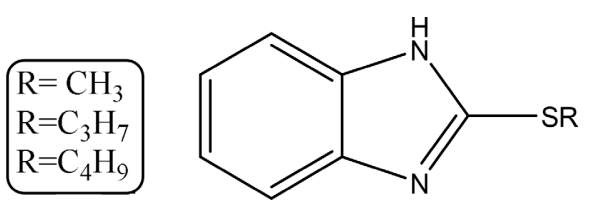

In conical flask weight (1.88 gm $0.01 \mathrm{~mol}$ ) of compound (2) Potassium salt add the corresponding alkyl halide (methyl chloride, propyl chloride and butyl chloride) ( $0.51 \mathrm{gm}, 0.79 \mathrm{gm}$ and. $93 \mathrm{gm}$ ) respectively and refluxed in DMF on water bath for 5 hours then allowed to cool, filtered dried and crystallized from ethanol.

The compound $14 \mathrm{a} \mathrm{R}=\mathrm{CH}_{3}$ yield, $70 \%$ (1.15 gm), Melting point: $220^{\circ} \mathrm{C}$ $222^{\circ} \mathrm{C}$, Molecular formula $\mathrm{C}_{8} \mathrm{H}_{8} \mathrm{~N}_{2} \mathrm{~S}$ (164) and the Microanalysis (CHN) the Calc. C: $58.51, \mathrm{H}: 4.91$ and $\mathrm{N} 17.60$ and the Found: C: $58.13, \mathrm{H}: 5.19$ and N 17.90 .

IR $\left(\mathrm{cm}^{-1}\right)$ : 3100 of aromatic, 3339 of $\mathrm{NH}$

${ }^{1} \mathrm{HNMR}(\mathrm{ppm}): 2.7\left(\mathrm{~s}, 3 \mathrm{H}, \mathrm{CH}_{3}\right), 2.7-8(\mathrm{~m}, 4 \mathrm{H}$, of aromatic protons and 10.2 
(s,1H, NH of the ring).

The compound $14 \mathrm{~b} \mathrm{R}=\mathrm{C}_{3} \mathrm{H}_{7}$ yield, $55 \%$ (1.56 gm), Melting point: $243^{\circ} \mathrm{C}$ $245^{\circ} \mathrm{C}$, Molecular formula $\mathrm{C}_{10} \mathrm{H}_{12} \mathrm{~N}_{2} \mathrm{~S}$ (192) and the Microanalysis (CHN) the Calc. C: 62.47, H: 6.29 and N 14.57 and the Found: C: 62.37, H: 6.09 and N 14.34

${ }^{1} \mathrm{HNMR}$ (ppm): 0.95 (s,3H, $\left.\mathrm{CH}_{3}\right), 1.41\left(\mathrm{~d}, 2 \mathrm{H}, \mathrm{CH}_{2}-\mathrm{CH}_{3}\right), 3.9\left(\mathrm{~d}, 2 \mathrm{H}, \mathrm{CH}_{2}-\mathrm{CH}_{2}\right)$, $7.3-8(\mathrm{~m}, 4 \mathrm{H}$, aromatic protons) and $12.3(\mathrm{~s}, 1 \mathrm{H}, \mathrm{NH}$ of the ring)

The compound $14 \mathrm{c} \mathrm{R}=\mathrm{C}_{4} \mathrm{H}_{9}$ yield, $50 \%$ (1.03 gm), Melting point: $260^{\circ} \mathrm{C}-$ $262^{\circ} \mathrm{C}$, Molecular formula $\mathrm{C}_{11} \mathrm{H}_{14} \mathrm{~N}_{2} \mathrm{~S}$ (206) and the Microanalysis (CHN) the Calc. C: 64.4, H: 6.84 and N 13.58 and the Found: C: 64.2, H: 6.89 and N 13.81

IR $\left(\mathrm{cm}^{-1}\right): 3115$ of aromatic and 3360 of $\mathrm{NH}$

${ }^{1} \mathrm{HNMR}$ (ppm): 94 (s, $\left.\mathrm{H}, \mathrm{CH}_{3}\right) 1.8$ (d,2H, $\mathrm{CH}_{2}-\mathrm{CH}_{3}$ ), 3.15 (d, $\mathrm{H}, \mathrm{CH}_{2} \mathrm{CH}_{2} \mathrm{CH}_{2} \mathrm{CH}_{3}$ ), $7.3-8(\mathrm{~m}, 4 \mathrm{H}$ aromatic protons) and $12.5(\mathrm{~s}, 1 \mathrm{H}, \mathrm{NH}$ of the ring).

\subsection{2-((1H-benzo[d]imidazol-2-yl) Thio) Acetamide (15)}<smiles>NC(=O)c1nc2ccccc2[nH]1</smiles>

The compound XV resulted from the reaction between $(0.01 \mathrm{~mol})$ of the compound $\left(3_{\mathrm{b}}\right)(2.36 \mathrm{gm})$ and ammonia gas (from reaction between $\left(\mathrm{NH}_{4}\right)_{2} \mathrm{CO}_{3}$ with $\mathrm{HCl})$. The ammonia collected via pipe into solution of compound $\left(3_{\mathrm{b}}\right)$ overnight then the compound (15) is formed Yield: $90 \%$ (1.99 gm) Melting point: $230^{\circ} \mathrm{C}$ $232^{\circ} \mathrm{C}$ Molecular weight: 221 , Molecular formula $\mathrm{C}_{8} \mathrm{H}_{4} \mathrm{~N}_{3} \mathrm{OS}$ ) and the Microanalysis (CHN) the Calc. C: 43.43, H: 4.07 and N 19.0 and the Found: C: $43.79, \mathrm{H}$ : 4.51 and $\mathrm{N} 18.75$.

IR $\left(\mathrm{cm}^{-1}\right)$ : $1695-\mathrm{CO}, 3235-\mathrm{NH}, 3335 \mathrm{NH}$ and 3110 for aromatic

${ }^{1} \mathrm{HNMR}$ (ppm): Signal at 5.1 for $\mathrm{CH}_{2}$, signals at 7.7 for aromatic protons and signal at 11.5 for $\mathrm{NH}$ of the ring.

\subsection{5-(((1H-benzo[d]imidazol-2-yl)thio)methyl)-1,3,4- oxadiazole-2-thiol $(16)$ and its Potassium salt $(16,17)$}

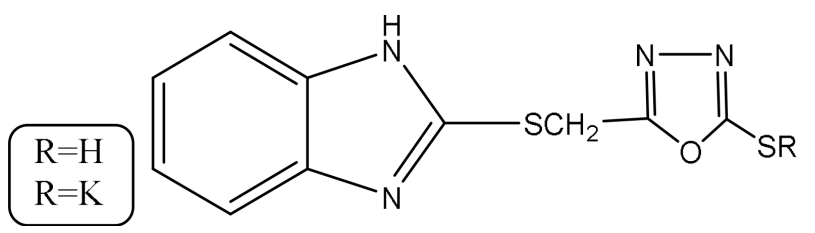

To the compound 2-((1H-benzo[d]imidazol-2-yl) thio) acetohydrazide (10) (2.36 gm) $(0.01 \mathrm{~mol})$ we add carbon disulfide $\mathrm{CS}_{2}(0.76 \mathrm{ml})$ excess and Potassium hydroxide $0.56 \mathrm{gm}$ in ethanol on heater, refluxed overnight and the compound resulted divided into two parts. One part left as it is and the second part poured onto $\mathrm{HCl} / \mathrm{H}_{2} \mathrm{O} 3: 1$ to resulted 2(2mercapto-oxadiazolemethylthio-benzimidazole). The compound of 2(2-mercaptooxadiazole) and its potassium salt crystalized from ethanol. 
The compound $16 \mathrm{R}=\mathrm{H}$ yield, $85 \%$ (2.25 gm), Melting point: $241^{\circ} \mathrm{C}-243^{\circ} \mathrm{C}$, Molecular formula $\mathrm{C}_{10} \mathrm{H}_{8} \mathrm{~N}_{4} \mathrm{OS}_{2}$ (264) and the Microanalysis (CHN) the Calc. C: 45.55, H: 3.03 and N 21.21 and the Found: C: 45.15, H: 2.98 and N 20.91.

${ }^{1} \mathrm{HNMR}$ of mercapto (compound 16) revealed signal peak at $15 \mathrm{ppm}$ for $\mathrm{SH}$, peak at $4.9 \mathrm{ppm}$ for $\mathrm{CH}_{2}$, peak at $7.7 \mathrm{ppm}$ for aromatic protons.

The compound $17 \mathrm{R}=\mathrm{K}$ yield, quantitively, Melting point $>300^{\circ} \mathrm{C}$, Molecular formula $\mathrm{C}_{10} \mathrm{H}_{7} \mathrm{~N}_{4} \mathrm{OS}_{2} \mathrm{~K}(302)$ and the Microanalysis (CHN) the Calc. C: $39.74, \mathrm{H}$ : 2.32 and $\mathrm{N} 18.44$ and the Found: C: 40, H: 1.91 and $\mathrm{N} 18.94$.

\section{Biological Testing}

\section{Experimental Animal}

Adult healthy female Wister albino rats weighting between 160 - 200 gm were used for the study. The animals were housed in standard conditions (temperature $24+2$ with 50\% - 60\% relative humidity and a 12-hour light dark cycle). All animals had free access to water and normal diet. The study was approved by Institutional Animal Ethical Committee (IAEC) and was in accordance with the guideline of the Committee for the Purpose of Control and Supervision of Experimental Animal (CPCSEA).

\subsection{In Vivo analgesic activity}

\section{Materials and Methods}

The animals were handled in accordance with the criteria outlined in the Guide for the Care and Use of Laboratory Animals. Swiss albino mice (22 $\pm \mathrm{gm})$, 6 - 8 weeks of age, were kept in a controlled environment $\left(22^{\circ} \mathrm{C} \pm 2{ }^{\circ} \mathrm{C}, 50 \% \pm\right.$ $5 \%$ humidity) under a 12-hour light/dark cycle and had free access to a standard pellet chow and tap water throughout the study. All experiments were conducted at Al-Azhar University Faculty of Pharmacy according to the recommendations of the ethics committee for animal welfare and have been approved by Institutional Animal Care and Utilization Committee No (1).

\section{Hot Plate Test.}

The hot plate test was used to calculate analgesic activity by the method explained by Eddy and Limbach (1953) [24] with minor modifications. Mice were retained on a hot plate having a stable temperature of $55^{\circ} \mathrm{C} \pm 1^{\circ} \mathrm{C}$. The time taken for either paw licking or jumping was recorded. Each mouse was individually placed on the hot plate in order to find the animal's reaction to electrical heat-induced pain (licking of the fore paws and eventually jumping). The latency until mice showed first signs of discomfort (hind paw lifting, hind paw licking, or jumping) were recorded, before (baseline), and response was determined after $60 \mathrm{~min}$ the administration of normal saline, indomethacin $(10 \mathrm{mg} / \mathrm{kg})$, and tested compounds $(100 \mathrm{mg} / \mathrm{kg})$. Data were analyzed using statistical software Graph Pad Prism version5. One-way analysis of variance (ANOVA) test was used to ascertain the significance of variations between the times of licking in hot plate test. All data were considered significant at $\mathrm{P}<0.05$. 


\section{Results}

The results in Table 1 show that the treatment of mice with indomethacin (10 $\mathrm{mg} / \mathrm{kg}$ orally) will increase the latency time while the treatment with voltarin (7 $\mathrm{mg} / \mathrm{kg}$ ) produce a significant increased the latency response in the hot plate test after 60 minutes of treatment from 10.17 to 19.50 and $25.67 \mathrm{sec}$. (91\% and 152.4 ,

Table 1. Analgesic effects of indomethacin, voltarin and tested compounds in comparison to control non-treated mice using hot plate method.

\begin{tabular}{|c|c|c|}
\hline Tested groups & Latency time (sec.) & $\begin{array}{l}\text { Percentage increase } \\
\text { in latency time }\end{array}$ \\
\hline Control & $10.17 \pm 1.5$ & - \\
\hline Indomethacin & $19.50 \pm 3.5$ & $91 \%$ \\
\hline Voltarin & $25.67 \pm 5.3^{a}$ & $152.4 \%$ \\
\hline 1 & $19.83 \pm 1.9$ & $95 \%$ \\
\hline $3 a$ & $35.17 \pm 7.3^{a}$ & $245.8 \%$ \\
\hline $3 b$ & $17.67 \pm 4.6$ & $73.7 \%$ \\
\hline $3 c$ & $22.33 \pm 7.4^{a}$ & $119.6 \%$ \\
\hline $5 a$ & $35.5 \pm 16.2^{a}$ & $249 \%$ \\
\hline $5 b$ & $22.17 \pm 10.8^{a}$ & $118 \%$ \\
\hline $5 c$ & $31.50 \pm 9.7^{a}$ & $209.7 \%$ \\
\hline 6 & $9 \pm 2.5$ & $-11.5 \%$ \\
\hline $7 a$ & $28.83 \pm 4.3^{a}$ & $183.5 \%$ \\
\hline $7 \mathrm{~b}$ & $29.00 \pm 6.2^{a}$ & $185 \%$ \\
\hline $7 \mathrm{c}$ & $29.67 \pm 6.0^{a}$ & $191.7 \%$ \\
\hline 8 & $17.83 \pm 5.2$ & 75.3 \\
\hline 9 & $13.00 \pm 6.9$ & $27.8 \%$ \\
\hline 10 & $20.17 \pm 7.4^{a}$ & $98.3 \%$ \\
\hline 11 & $26.50 \pm 3.8^{a}$ & $160.6 \%$ \\
\hline 12 & $39.33 \pm 6.0^{a}$ & $286.7 \%$ \\
\hline $13 a$ & $17.83 \pm 6.4$ & $75.3 \%$ \\
\hline $13 b$ & $23.17 \pm 11.9^{a}$ & $127.8 \%$ \\
\hline $13 \mathrm{C}$ & $36.17 \pm 14.1^{a}$ & $255.6 \%$ \\
\hline $14 \mathrm{a}$ & $11.7 \pm 4.4$ & $-15 \%$ \\
\hline $14 \mathrm{~b}$ & $33.17 \pm 6.6^{a}$ & $226 \%$ \\
\hline $14 \mathrm{c}$ & $25.17 \pm 10.9^{a}$ & $147.5 \%$ \\
\hline 15 & $21.57 \pm 9.9^{a}$ & $112 \%$ \\
\hline 16 & $18.83 \pm 4.3$ & $85.15 \%$ \\
\hline 17 & $10.00 \pm 2.4$ & $-1.7 \%$ \\
\hline
\end{tabular}


respectively). On the other hand, oral treatment of compounds $(6,9,14 \mathrm{a}$ and 17$)$ showed no significant influence on the reaction time of the animals to the hot plate at dose of $100 \mathrm{mg} / \mathrm{kg}$ by mild changes in the latency time by $(-11.5 \%$, $27.8 \%, 15 \%$ and $-1.7 \%$, respectively), while compounds (3b, 8, 13a, and 16 ) showed mild and no significant increase by $(73.7 \%, 75.3 \%, 75.3$ and $85.15 \%$, respectively) when compared to control no treated group, after oral treatment of compound (I) in a dose of $100 \mathrm{mg} / \mathrm{kg}$ the latency time was moderately increased by (95\%) only the compounds (3c, 10,11,13b,14c and 15) showed significant increase in latency time by $(119.6 \%, 98.3 \%, 160.6 \%, 127.8 \%, 147.5 \% 112 \%$, $98.3 \%$ and $118 \%$, respectively) when compared to control no treated group, while the other compounds (3a, 5c, 7a, 7b, 7c, 12, 14b and 17) in this group showed a highly significant increase in latency time by $(147.5 \%, 209.7 \%, 183.5 \%$, $185 \%, 191.7 \% 226 \%$ and $245 \%$, respectively) when compared to control non treated group, finally the last two drugs (12 and 13c) produce a very significant increase in latency time in hot plate for about (286.7 and $255.6 \%$, respectively) in a dose of $100 \mathrm{mg} / \mathrm{kg}$ when compared to negative control group.

And the new synthesized drugs action can be illustrated against control, voltarin and indomethacin as the following figures (Figure 1 to Figure 4).

\section{Discussion}

In this experiment the treatment with indomethacin produce elevation in latency time, voltarin produce a significant in-crease in latency time when compared to control animals. Compounds (12 and 13c) showed a very highly significant in-crease in latency time, while a highly significant increase in latency was obtained with treatment of compounds ( $3 a, 5 c, 7 a-c, 14 b$ ), a mild significant increase in response was observed during carried out the experiment with compounds $(3 c, 10,11,13 b, 14 c, 15$, and $5 b)$, finally there is no significant increase

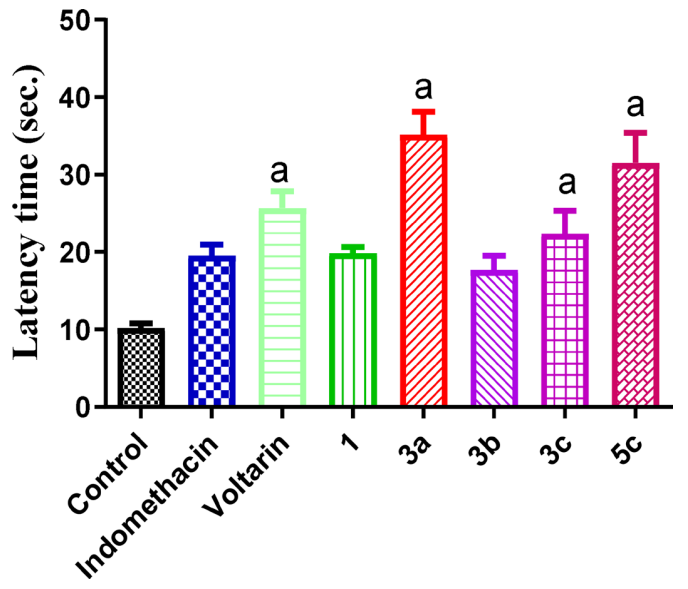

Indomethacin $(10 \mathrm{mg} / \mathrm{kg})$, voltarin $(7 \mathrm{mg} / \mathrm{kg})$, tested compounds $(100 \mathrm{mg} / \mathrm{kg})$, was given orally one hour before carried out the experiment. A Significantly different from control group. Using one-way ANOVA followed by Tukey-Kramer test for multiple comparisons at $\mathrm{P} \leq 0.05$.

Figure 1. Analgesic effects of indomethacin, voltarin and tested compounds (1, 3a, 3b, 3c and 5c) in comparison to control non-treated mice using hot plate method. 


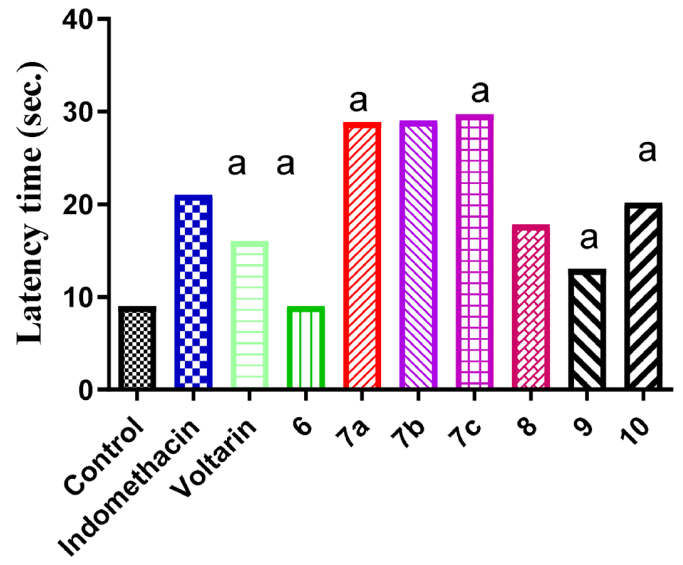

Data are expressed as means \pm SD of six mice per group. Indomethacin $(10 \mathrm{mg} / \mathrm{kg})$, voltarin $(7 \mathrm{mg} / \mathrm{kg})$ tested compounds $(100 \mathrm{mg} / \mathrm{kg})$, was given orally one hour before carried out the experiment. A Significantly different from control group. Using one-way ANOVA followed by Tukey-Kramer test for multiple comparisons at $\mathrm{P} \leq 0.05$.

Figure 2. Analgesic effects of indomethacin, voltarin and tested compounds (6, 7a, 7b, 7c, 8,9 and 10) in comparison to control non-treated mice using hot plate method.

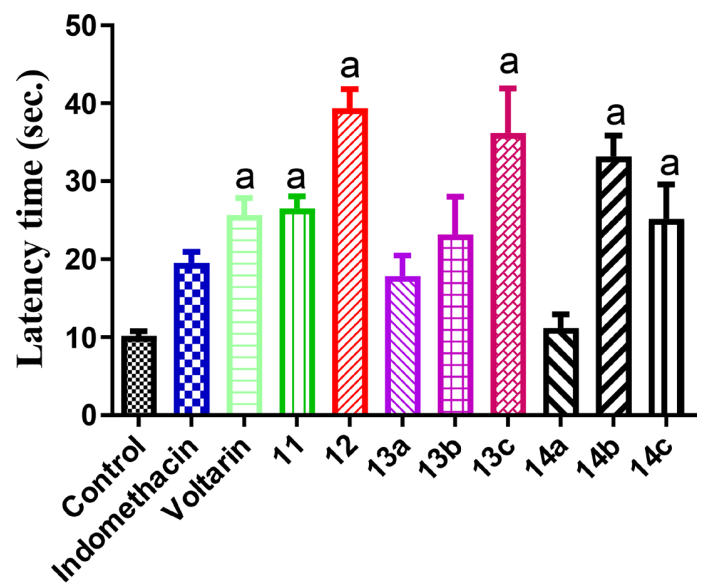

Data are expressed as means \pm SD of six mice per group. Indomethacin (10 mg/kg), tested compounds $(100 \mathrm{mg} / \mathrm{kg})$, was given orally one hour before carried out the experiment. a Significantly different from control group. Using one-way ANOVA followed by Tukey-Kramer test for multiple comparisons at $\mathrm{P} \leq 0.05$.

Figure 3. Analgesic effects of indomethacin, voltarin and tested compounds $(11,12,13 \mathrm{a}$, $13 \mathrm{~b}, 13 \mathrm{c}, 14 \mathrm{a}, 14 \mathrm{~b}$ and 14c) in comparison to control non-treated mice using hot plate method.

in latency time for the remaining compounds when compared to non-treated animals.

\subsection{In Vitro Cytotoxicity Activity}

In vitro cytotoxicity against the MCF7 and HepG2 cell lines and against human normal cell (Cell culture Protocol).

Cell Line (MCF7 and HepG2) was attained from the American Type Culture Collection. 


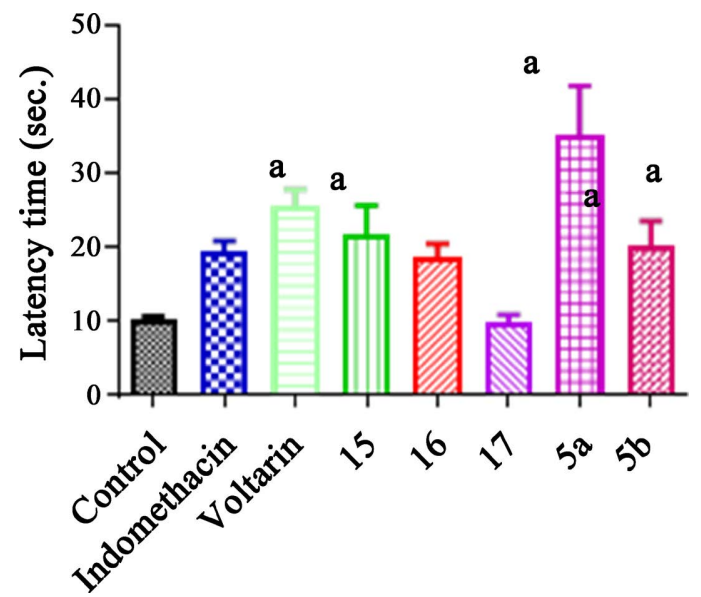

Data are expressed as means \pm SD of six mice per group. Indomethacin $(10 \mathrm{mg} / \mathrm{kg})$, voltarin $(7 \mathrm{mg} / \mathrm{kg})$ tested compounds $(100 \mathrm{mg} / \mathrm{kg})$, was given orally one hour before carried out the experiment. a Significantly different from control group. Using one-way ANOVA followed by Tukey-Kramer test for multiple comparisons at $\mathrm{P} \leq 0.05$.

Figure 4. Analgesic effects of indomethacin, voltarin and tested compounds $(15,16,17$, $5 \mathrm{a}$, and $5 \mathrm{~b}$ ) in comparison to control non-treated mice using hot plate method. Data are expressed as means \pm SD of six mice per group. Indomethacin $(10 \mathrm{mg} / \mathrm{kg})$, voltarin $(7$ $\mathrm{mg} / \mathrm{kg}$ ) tested compounds $(100 \mathrm{mg} / \mathrm{kg}$ ), was given orally one hour before carried out the experiment. a Significantly different from control group. Using one-way ANOVA followed by Tukey-Kramer test for multiple comparisons at $\mathrm{P} \leq 0.05$.

Cells were cultured by using DMEM augmented with $10 \%$ fetal bovine serum $10 \mathrm{ug} / \mathrm{ml}$ of insulin (Sigma), and 1\% penicillin-streptomycin. All of the additional chemicals and reagents were taken from Sigma or Invitrogen. Cells were spread in a 96-well flat-bottom microliter plate at a density of 10,000 cells/well and allowed to follow for 24 hours at $37^{\circ} \mathrm{C}$ in $\mathrm{CO}_{2}$ incubator. After 24 hours of incubation. The growth medium was exchanged with a fresh medium. Cells were then supplied with different concentrations of the desired compound for 24 hours at $37^{\circ} \mathrm{C}$. After 24 hours of incubation, the growth medium was changed with a fresh medium. Subsequently [25], $10 \mu \mathrm{l}$ of MTT working solution (5 $\mathrm{mg} / \mathrm{mL}$ in phosphate buffer solution) was added to each well and the plate was hatched for 4 hours at $37^{\circ} \mathrm{C}$ in incubator [26]. The medium was then extracted, and the produced formazan crystals were solubilized by adding $50 \mathrm{~L}$ of DMSO per well for $30 \mathrm{~min}$ at $37^{\circ} \mathrm{C}$ in a $\mathrm{CO}_{2}$ incubator. Lastly, the intensity of the dissolved crystals. (Purple color) was counted using the ROBONIK P2000 ELISA reader at $540 \mathrm{~nm}$ with a reference wavelength set at $650 \mathrm{~nm}$. The suspension was moved to the cuvette of a spectrophotometer and the OD values were measured at $595 \mathrm{~nm}$ by using DMSO as a blank [27], measurements were achieved and the concentration needed for a $50 \%$ inhibition of viability (Cs) was determined graphically Standard Graph was plotted by taking the log. The concentration of the drug in the $\mathrm{X}$-axis and relative cell viability in the $\mathrm{Y}$-axis.

Systematic experimental steps were taken to set the potential cytotoxicity of the drug at different concentrations by MTT assay. It shows a decreasing absorbance at $540 \mathrm{~nm}$ in the cells which were treated with increasing concentration of 
the drug in comparison to the control cells without any treatment. There is a decreased absorbance in the cells treated with drugs suggesting cytotoxicity. MTT assay significantly helps the researchers to determine whether any of the test compounds have cell toxicity or proliferative activity. All data were measured in triplicate, and IC50 values are given as mean values USD.

Cytotoxic activity of some compounds against human tumor cells

\begin{tabular}{|c|c|c|c|}
\hline \multirow{2}{*}{ No. } & \multirow{2}{*}{ Comp. } & \multicolumn{2}{|c|}{ In vitro Cytotoxicity IC50 $(\mu \mathrm{M}) \bullet$} \\
\hline & & HePG-2 & MCF-7 \\
\hline$\bullet$ & DOXORUBICIN & $4.50 \pm 0.3$ & $4.17 \pm 0.2$ \\
\hline 1 & 1 & $65.62 \pm 3.4$ & $53.40 \pm 3.3$ \\
\hline 2 & $3 a$ & $100>$ & $100>$ \\
\hline 3 & $3 b$ & $100>$ & $100>$ \\
\hline 4 & $3 c$ & $100>$ & $84.71 \pm 4.4$ \\
\hline 5 & $5 \mathrm{a}$ & $100>$ & $100>$ \\
\hline 6 & $5 b$ & $93.01 \pm 4.9$ & $78.29 \pm 4.0$ \\
\hline 7 & $5 c$ & $81.35 \pm 4.2$ & $69.48 \pm 3.7$ \\
\hline 8 & 6 & $39.42 \pm 2.6$ & $42.23 \pm 2.9$ \\
\hline 9 & $7 \mathrm{c}$ & $86.35 \pm 4.4$ & $67.51 \pm 3.5$ \\
\hline 10 & 8 & $48.28 \pm 2.8$ & $45.67 \pm 3.0$ \\
\hline 11 & $3 c$ & $39.52 \pm 3.6$ & $44.65 \pm 1.8$ \\
\hline 12 & 9 & $32.16 \pm 2.4$ & $37.20 \pm 2.6$ \\
\hline 13 & 10 & $52.04 \pm 2.9$ & $38.17 \pm 2.5$ \\
\hline 14 & 11 & $19.87 \pm 1.6$ & $14.35 \pm 1.2$ \\
\hline 15 & $13 \mathrm{a}$ & $73.55 \pm 3.6$ & $57.18 \pm 3.4$ \\
\hline 16 & $13 b$ & $64.19 \pm 3.3$ & $49.65 \pm 3.1$ \\
\hline 17 & $13 c$ & $58.29 \pm 3.1$ & $31.48 \pm 2.3$ \\
\hline 18 & $14 \mathrm{a}$ & $100>$ & $100>$ \\
\hline 19 & $14 \mathrm{~b}$ & $100>$ & $100>$ \\
\hline 20 & $14 c$ & $100>$ & $74.19 \pm 3.9$ \\
\hline 21 & 15 & $29.71 \pm 2.3$ & $17.26 \pm 1.4$ \\
\hline 22 & 16 & $26.10 \pm 2.1$ & $28.06 \pm 2.2$ \\
\hline 23 & 17 & $8.71 \pm 0.7$ & $7.18 \pm 0.5$ \\
\hline
\end{tabular}

- IC50 ( $\mu \mathrm{M}): 1$ - 10 (very strong). 11 - 20 (strong). 21 - 50 (moderate). 51 - 100 (weak) and above 100 (non-cytotoxic). Cell viability $(\%)=$ mean $O D /$ control $O D \times 100 \%$. Where $\mathrm{OD}=$ optical density.

\section{Molecular Modeling}

A major challenge of modern medicine is to design compounds that modulate specific enzymes while leaving related isozymes unaffected. The two notable enzymes namely Cyclooxygenase-2 (COX-2) and inducible Nitric Oxide Synthase (iNOS) are important mediators of an inflammatory process. 
Nonsteroidal Anti-inflammatory drugs (NSAIDs) like Indomethacin act via inhibition of COX enzyme which catalyzes the first step of the biosynthesis of prostaglandins [28].

Prostaglandins (PGs), found in most of the tissues and organs, are the arachidonic acid metabolites of the Cyclooxygenase (COX) pathway and are major mediators in the regulation of the inflammation and immune function [29]. It has been shown that the COX enzyme exists in two isoforms COX-1 and COX-2 [30]. In terms of amino acid composition, these enzymes are approximately $60 \%$ identical, and their catalytic regions are widely conserved [31] [32] [33]. COX-1 enzyme is responsible for maintaining gastric and renal integrity and COX-2 is an inducible enzyme responsible for the production of proinflammatory PGs causing inflammation and pain [34].

The COX-2 inhibitors are effective for the relief of chronic pain in elderly patients with osteoarthritis and rheumatoid arthritis [35].

Inducible Nitric Oxide Synthase (iNOS), is another inducible enzyme, that plays a significant role in the over production of nitric oxide (NO) and has been implicated in several pathophysiological states, for example; various inflammation, septic shock, vascular dysfunction in diabetes and cancer patients [36] [37] [38].

Three homologous NOS isozymes [inducible NOS (iNOS), endothelial NOS (eNOS), and neuronal NOS (nNOS)] catalyze the five-electron, two-step oxidation of $\mathrm{L}$-arginine ( $\mathrm{L}-\mathrm{Arg}$ ) to form nitric oxide which is an important biological signaling molecule and cellular cytotoxin [39]. The constitutive isozymes, eNOS and nNOS, function to produce low levels of NO predominantly for blood pressure regulation and nerve function respectively. In contrast, iNOS is induced by microbial products, such as lipopolysaccharide (LPS) and inflammatory cytokines such as interleukin-1 (IL-1), tumor necrosis factor- $\alpha$ (TNF- $\alpha$ ) and interferon- $\gamma$ (INF- $\gamma$ ) in macrophages and some other cells [40]. COX-2 and iNOS over expression has been observed in many human invasive malignant tumors, e.g. breast, lung, prostate, bladder, colorectal cancer and malignant melanoma [41] [42] [43].

Therefore, the modulation of iNOS and COX-2 can be a good strategy for the management of diseases accompanying the overproduction of NO and PGs.

With our long-standing interest in the transcriptional regulation-based control of inflammation, the objectives of the present study are to obtain binding and inhibitory parameters of Benzimidazole derivatives and Indomethacin (NSAID) on COX-2 and iNOS by means of (MOE) prediction of their absorption and distribution properties.

\section{Material and Methods}

Carrageenan induced paw oedema in rats the anti-inflammatory activity of Benzimidazole derivatives was determined by inducing acute in vivo and in silico Analysis Divulges the Anti-Inflammatory Activity inflammation by carrageenan in rats [44]. The Institutional Animal Ethical Committee approved protocols 
that were followed for experimental analysis. All the animals were acclimatized for a week before use and were grouped in polyacrylic cages and maintained under standard laboratory conditions. The room temperature was maintained at $25^{\circ} \mathrm{C} \pm 2{ }^{\circ} \mathrm{C}$ with dark and light cycle of $14 / 10 \mathrm{~h}$. They were fed on commercial diet and water ad libitum. The rats were divided into five groups of six animals each. The first group, referred as control received normal saline $(0.9 \% \mathrm{w} / \mathrm{v}, 3$ $\mathrm{ml} / \mathrm{kg} / \mathrm{p} . \mathrm{o})$. Second group with Indomethacin $(10 \mathrm{mg} / \mathrm{kg} / \mathrm{p} . \mathrm{o})$ served as standard whereas third, fourth and fifth groups were orally administered with 0.5 $\mathrm{mg} / \mathrm{kg} / \mathrm{p} . \mathrm{o}, 5 \mathrm{mg} / \mathrm{kg} / \mathrm{p}$. o and $10 \mathrm{mg} / \mathrm{kg} / \mathrm{p}$.o of Benzimidazole derivatives respectively with the help of an oral catheter. Food was withdrawn overnight but an adequate supply of water was given to rats before the experiments.

After $1 \mathrm{~h}$ of drug treatment, a supplanter injection of $1 \%$ solution of carrageenan was administered in the left hind paw of all five groups. The volume of paw oedema was measured with caliper after $3 \mathrm{~h}$ of injections. The average paw volume was calculated and compared with control and standard to determine the anti-inflammatory activity.

Preparation of protein structures and prediction of binding sites

The experimental coordinates of COX-2 (PDB_ID:1CX2) and iNOS (PDB_ID: 1NS1) structures were taken from PDB. The active sites of COX-2 and iNOS were identified using CASTp server [18] [45] based on precise computational geometry methods, including alpha shape and discrete flow theory. Among the active site residues, the important residues were selected compared to previous data [46] [47]. Ligands were removed from the binding sites and the chain A was selected for COX-2 and chain B for iNOS docking studies. Hetero atoms were removed and polar hydrogen atoms were added to protein structures and partial atomic charges were assigned. The proteins are saved in MOL2 format; atomic solvation parameters were assigned and converted finally into PDBQS format.

\section{Preparation of ligand structures}

The molecular structures of Benzimidazole derivatives and Indomethacin were generated and optimized using ChemSketch software. The ligands are saved in PDBQ format using Deftors to define torsions during docking.

\section{Molecular docking}

Docking of Benzimidazole derivatives and Indomethacin was carried out against COX-2 and iNOS using MOE which is widely distributed public domain molecular docking software, was used in this study. MOE consists of the components like Auto Grid and AutoTors and uses Monte Carlo simulated annealing and Lamarckian genetic algorithm to create a set of possible conformations. This program addresses automatically the flexible docking of the ligands into a known protein structure.

The proteins for each docking were kept rigid and torsional flexibility was permitted to the ligands. The rotatable bonds in the ligands were defined using AutoTors and grid maps were calculated using Auto Grid. The search was conducted in a grid point of $48 \times 54 \times 62$ for COX- 2 and $52 \times 56 \times 48$ for iNOS in 
three dimensions built in $\mathrm{x}, \mathrm{y}$, and $\mathrm{z}$ directions with $0.375 \mathrm{~A}^{\circ}$ spacing centered on the binding site of macromolecules and each docking experiment consisted of 10 docking runs with 150 individuals. The default settings were used for all other parameters. The resultant structure files were analyzed using RasMol visualization programs. The MOE result gives the binding position, bound conformation of the peptide and a rough estimate of its activity.

\section{Pharmacokinetic Properties}

The bioavailability of Benzimidazole derivatives and Indomethacin was determined using PK/DB Database. The ligand structures were manually entered or edited using PK/DB sketcher, then converted into SMILES format and searched for pharmacokinetic properties like human intestinal absorption (\%HIA), human oral bioavailability $(\% \mathrm{~F})$, plasma protein binding (\%PPB), blood brain barrier $(\operatorname{logBB})$ and water solubility $(\log S)$.

Hologram QSAR Technique [48] [49]

Results (from Figure 5 to Figure 12)

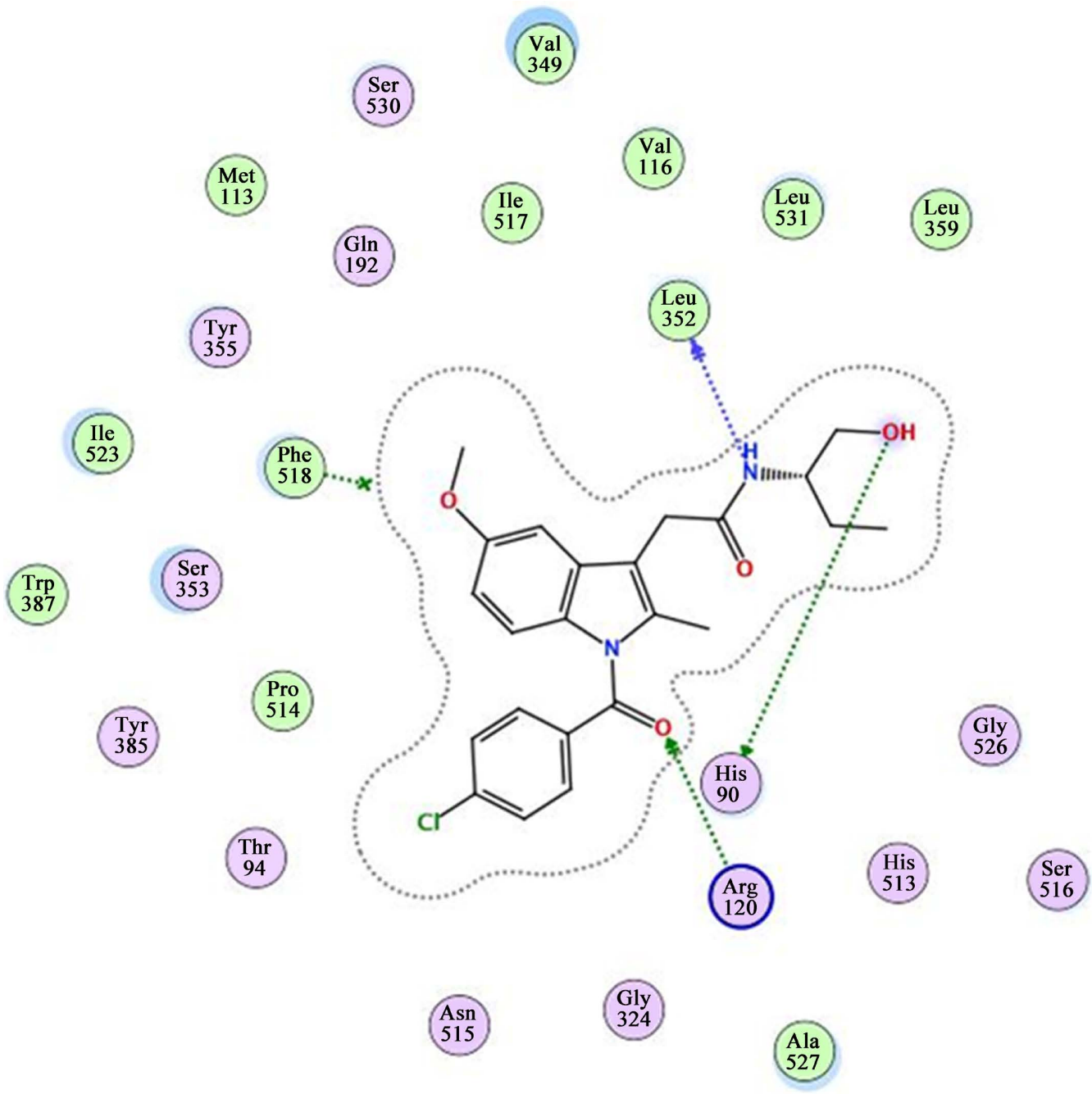

Figure 5. Indomethacin binds to COX-1 receptor in which the legend binds to COX I receptor by bonds between $\mathrm{OH}$ and His 90, carbonyl and Arg 120 and NH and Leu 352 . 


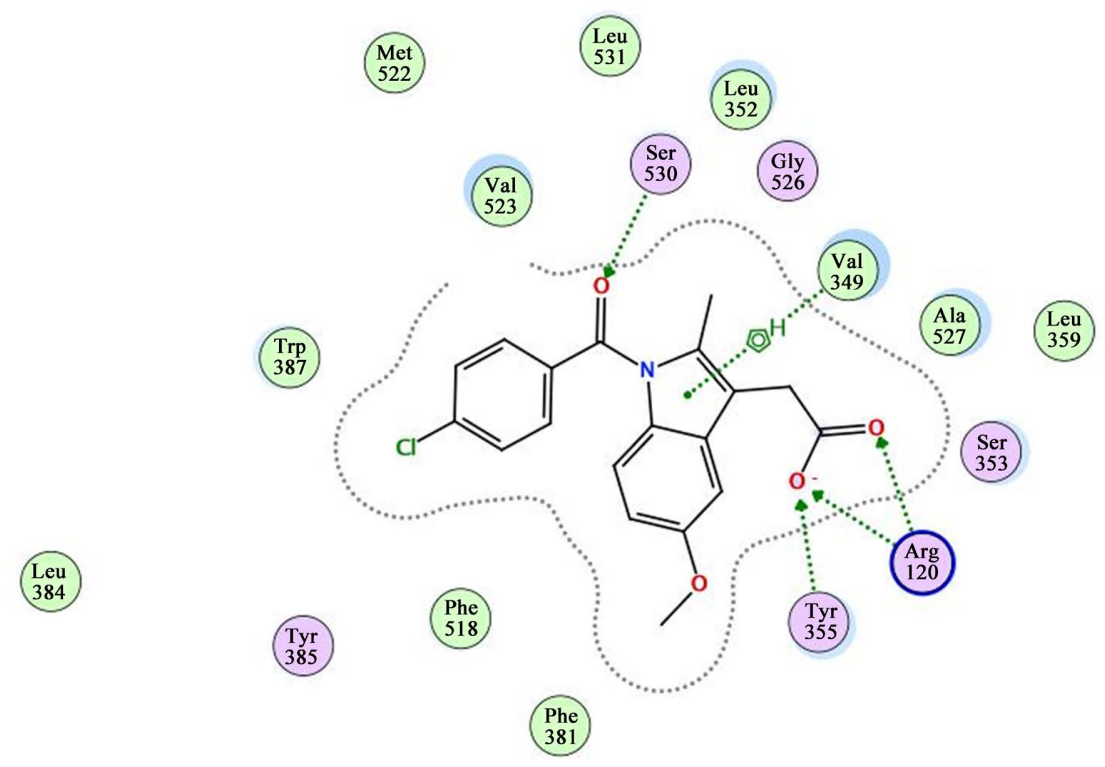

His
90

Figure 6. Indomethacin binds to COX II receptor With 5 hydrogen bonds.

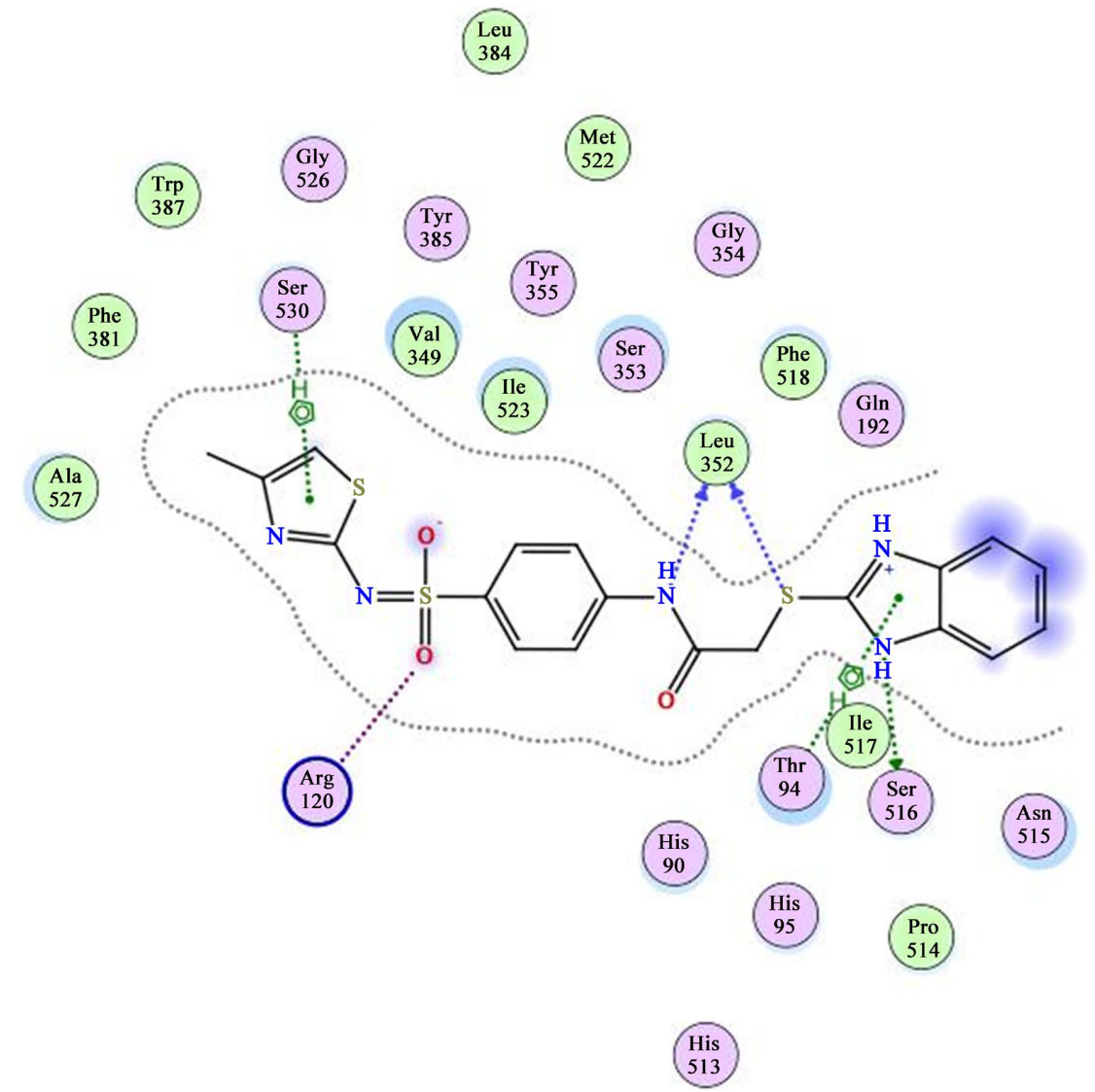

Figure 7. The compound (5c) binds to COX 1 receptors by 6 bonds which binds between the NH of benzimidazole an Ser 516, the imidazole rig and Thr 94, S group of mercaptobenzimidazole and Leu 352 and the $\mathrm{SO}_{2}$ group sulfathiazole group and Arg 120 and between thiazole ring and Ser 530. 


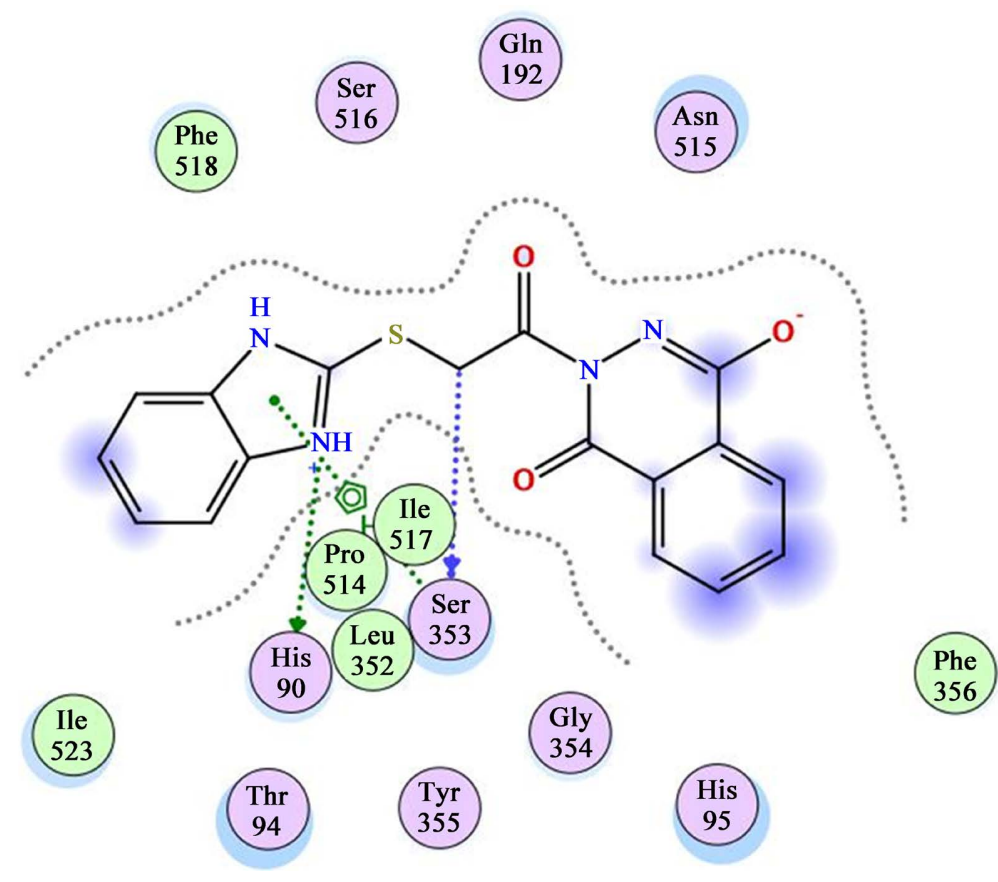

Figure 8. The binding mode of compound (12) with COX-II enzyme forming 3 hydrogen bonds between $\mathrm{CH}_{2}$ and Ser 353, the benzimidazole ring and Ser 353 and $\mathrm{NH}$ of benzimidazole and His 90.

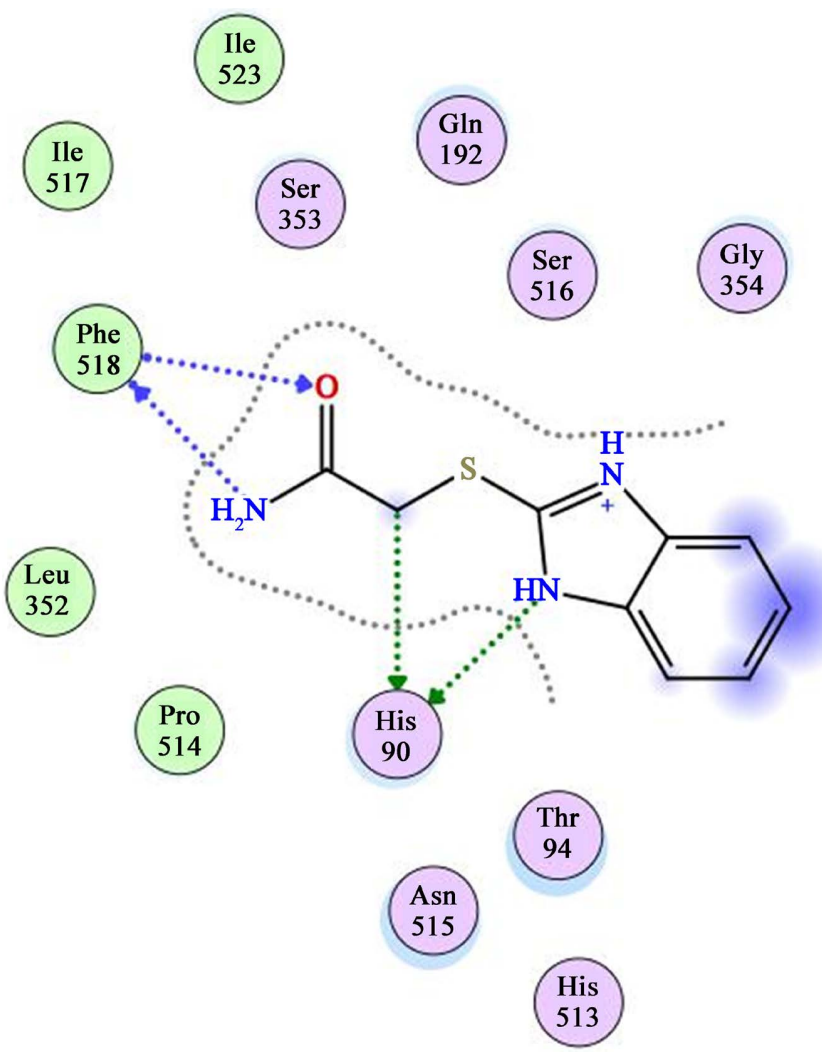

Figure 9. The binding mode of compound (15) with $\mathrm{COX}$ His $90, \mathrm{CH}_{2}$ and His 90 , O of carbonyl group and Phe 518 and terminal $\mathrm{NH}_{2}$ with Phe 518 II enzyme forming 4 bonds between $\mathrm{NH}$ of benzimidazole. 


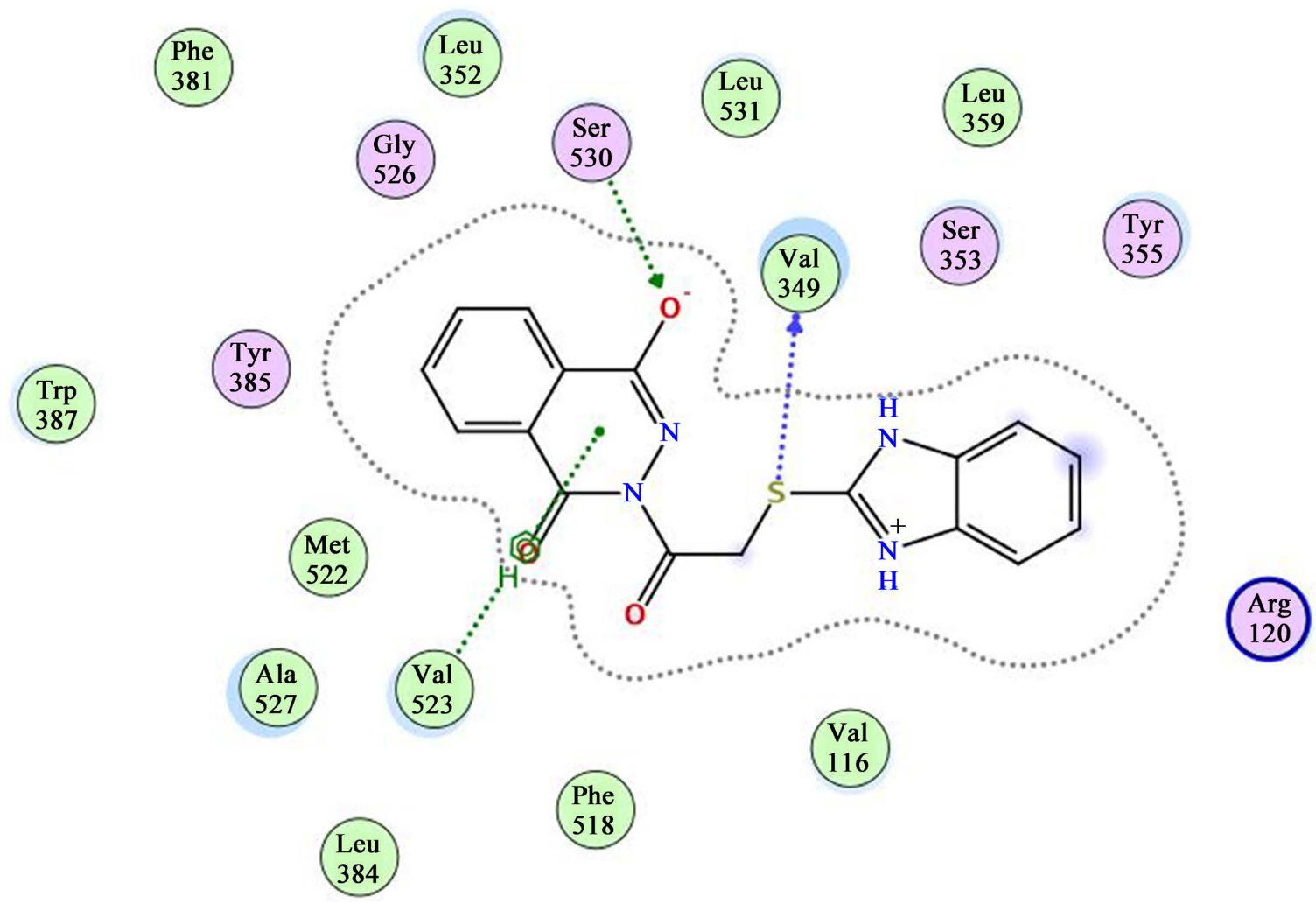

Figure 10. The compound (12) binds with the protein of COX II by 3 hydrogen bonds.

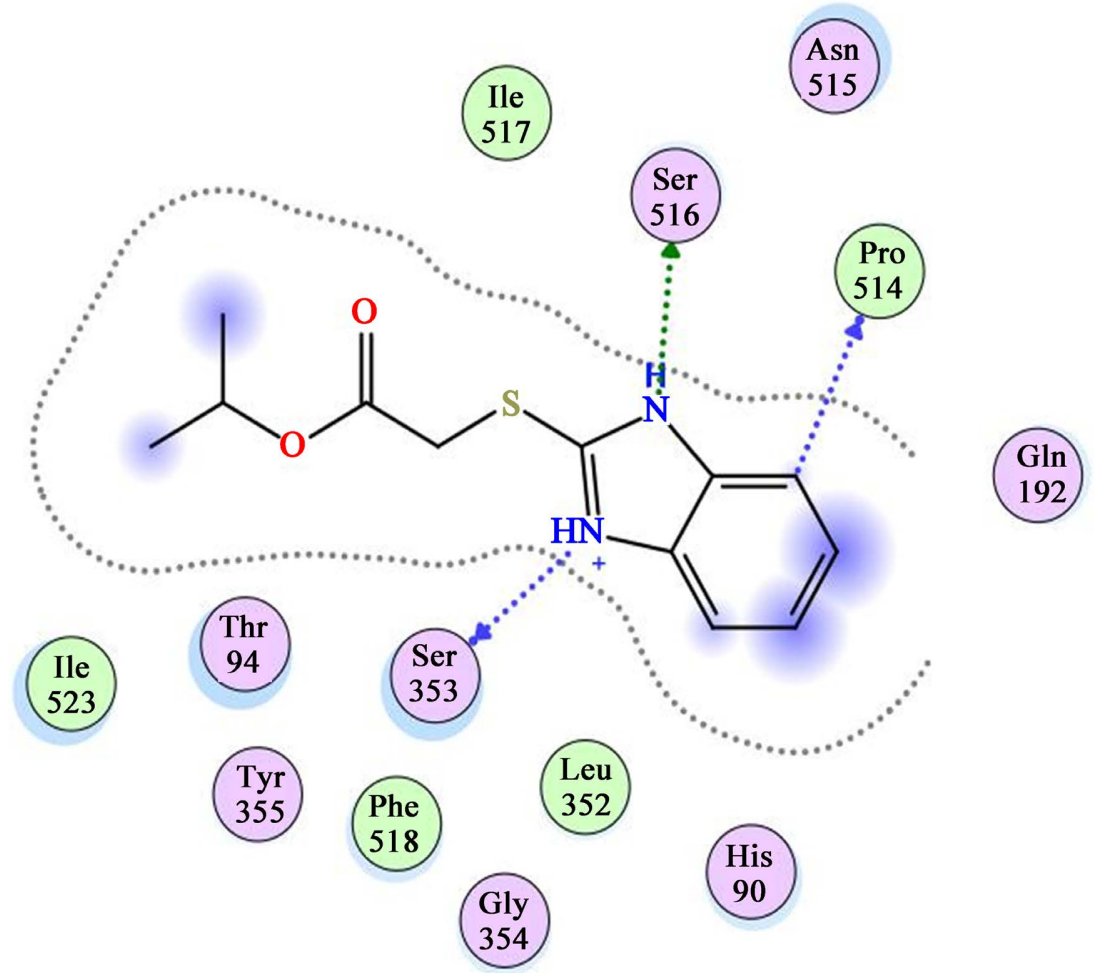

Figure 11. The binding mode of compound (3c) with COX-II enzyme forming 3 bonds between both NH of benzimidazole ring and Ser 353 and Ser 516 and between benzene ring of benzimidazole and Pro 514. 


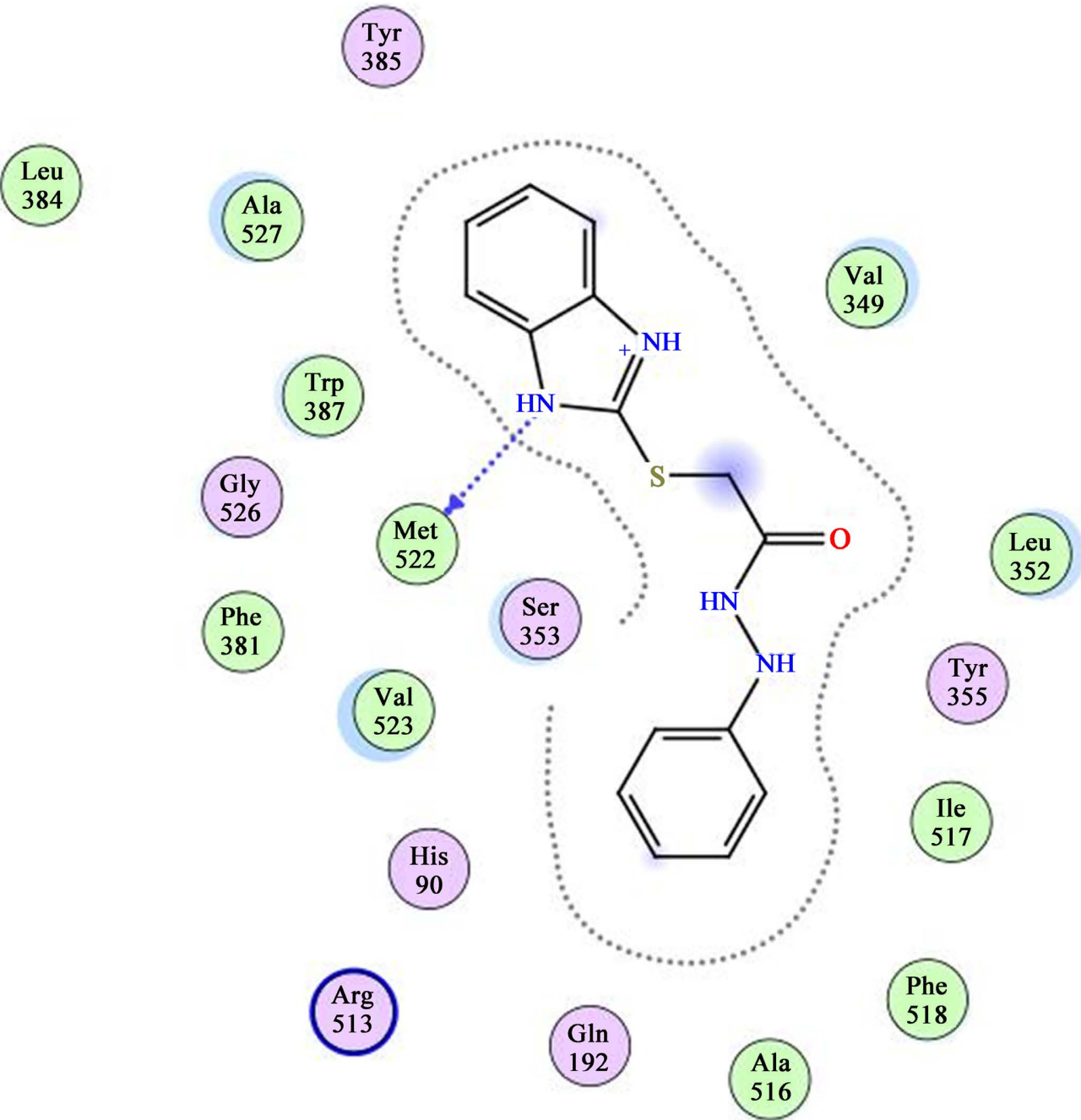

Figure 12. The compound (11) binds with the protein of COX II receptor by 1 hydrogen bonds.

\section{Conflicts of Interest}

The authors declare no conflicts of interest regarding the publication of this paper.

\section{References}

[1] El-Helby, A.-G., Sakr, H., Ayyad, R., Mahdi, H., et al. (2020) Design, Synthesis, Molecular Modeling, in Vivo Studies and Anticancer Activity Evaluation of New Phthalazine Derivatives as Potential DNA Intercalators and Topoisomerase II Inhibitors. Bioorganic Chemistry, 103, Article ID: 104233. https://doi.org/10.1016/j.bioorg.2020.104233

[2] Ayyad, R.R. (2012) Synthesis and Biological Evaluation of Novel Iodophthalazinedione Derivatives as Anticonvulsant Agents. Al-Azhar Journal of Pharmaceutical Sciences, 45, 1-13. https://doi.org/10.21608/ajps.2012.7146

[3] Eldehna, W.M., Abou-Seri, S.M., El Kerdawy, A.M., Ayyad, R.R., et al. (2016) Increasing the Binding Affinity of VEGFR-2 Inhibitors by Extending Their Hydrophobic Interaction with the Active Site: Design, Synthesis and Biological Evaluation of 1-substituted-4-(4-methoxybenzyl) Phthalazine Derivatives. European Journal of 
Medicinal Chemistry, 113, 50-62. https://doi.org/10.1016/j.ejmech.2016.02.029

[4] El-Helby, A.G.A., Ayyad, R.R., Sakr, H.M., Abdulrahim, A.S., et al. (2017) Design, Synthesis, Molecular Modeling and Biological Evaluation of Novel 2, 3-Dihydrophthalazine-1,4-dione Derivatives as Potential Anticonvulsant Agents. Journal of Molecular Structure, 1130, 333-351. https://doi.org/10.1016/j.molstruc.2016.10.052

[5] El-Helby, A.-G.A., Ayyad, R.R.A., Sakr, H., El-Adl, K., Ali, M.M., et al. (2017) Design, Synthesis, Molecular Docking, and Anticancer Activity of Phthalazine Derivatives as VEGFR-2 Inhibitors. Archiv der Pharmazie, 350, Article ID: 1700240. https://doi.org/10.1002/ardp.201700240

[6] El-Helby, A.-G.A., Ayyad, R.R.A., El-Adl, K. and Elkady, H. (2019) Phthalazine-1,4-dione Derivatives as Non-Competitive AMPA Receptor Antagonists: Design, Synthesis, Anticonvulsant Evaluation, ADMET Profile and Molecular Docking. Molecular Diversity, 23, 283-298. https://doi.org/10.1007/s11030-018-9871-y

[7] Eissa, I.H., Metwally, A.M., Belal, A., Mehany, A.B.M., et al. (2019) Discovery and Antiproliferative Evaluation of New Quinoxalines as Potential DNA Intercalators and Topoisomerase II Inhibitors. Archiv der Pharmazie, 352, Article ID: 1900123. https://doi.org/10.1002/ardp.201900123

[8] Ibrahim, M.-K., Abd-Elrahman, A.A., Ayyad, R.R.A., El-Adl, K., et al. (2013) Design and Synthesis of Some Novel 2-(3-methyl-2-oxoquinoxalin-1 (2H)-yl)-N-(4-(substituted) phenyl) Acetamide Derivatives for Biological Evaluation as Anticonvulsant Agents. Bulletin of Faculty of Pharmacy, Cairo University, 51, 101-111.

https://doi.org/10.1016/j.bfopcu.2012.11.003

[9] Elhelby, A.A., Ayyad, R.R. and Zayed, M.F. (2011) Synthesis and Biological Evaluation of Some Novel Quinoxaline Derivatives as Anticonvulsant Agents. Arzneimittelforschung, 61, 379-381. https://doi.org/10.1055/s-0031-1296214

[10] El-Helby, A.-G.A., Ayyad, R.R.A., El-Adl, K. and Elwan, A. (2017) Quinoxalin-2 (1H)-One Derived AMPA-Receptor Antagonists: Design, Synthesis, Molecular Docking and Anticonvulsant Activity. Medicinal Chemistry Research, 26, 2967-2984. https://doi.org/10.1007/s00044-017-1996-5

[11] El-Helby, A.-G.A., Ayyad, R.R.A., Zayed, M.F., Abuelkheer, H.S., et al. (2019) Design, Synthesis, in Silico ADMET Profile and GABA-A Docking of Novel Phthalazines as Potent Anticonvulsants. Archiv Der Pharmazie, 352, Article ID: 1800387. https://doi.org/10.1002/ardp.201800387

[12] El-Helby, A.-G.A., Sakr, H., Ayyad, R.R.A., El-Adl, K., et al. (2018) Design, Synthesis, in Vitro Anti-Cancer Activity, ADMET Profile and Molecular Docking of Novel Triazolo[3, 4-a]phthalazine Derivatives Targeting VEGFR-2 Enzyme. Anti-Cancer Agents in Medicinal Chemistry, 18, 1184-1196. https://doi.org/10.2174/1871520618666180412123833

[13] Mohd Nassar, E., Abdelrazek, F.M., Ayyad, R.R. and El-Farargy, A.F. (2016) Synthesis and Some Reactions of 1-Aryl-4-acetyl-5-methyl-1,2,3-triazole Derivatives with Anticonvulsant Activity. Mini-Reviews in Medicinal Chemistry, 16, 926-936. https://doi.org/10.2174/1389557516666160118105505

[14] Ayyad, R. (2014) Synthesis and Anticonvulsant Activity of 6-Iodo Phthalazinedione Derivatives. Al-Azhar Journal of Pharmaceutical Sciences, 50, 43-54.

https://doi.org/10.21608/ajps.2016.6930

[15] El-Helby, A.-G.A., Ibrahim, M.K., Abdel-Rahman, A.A., Ayyad, R.R.A., Menshawy, M.A. and El-Adl, K. (2009) Synthesis, Molecular Modeling and Anticonvulsant Activity of Benzoxazole Derivatives. Al-Azhar Journal of Pharmaceutical Sciences, 40, $252-270$. 
[16] Ayyad, R.R.A., Sakr, H. and El-Gamal, K. (2016) Synthesis, Modeling and Anticonvulsant Activity of Some Phthalazinedione. American Journal of Organic Chemistry, 6, 29-38.

[17] Ayyad, R.R.A. (2008) Synthesis and Anticonvulsant Activity of Tetrabromophthalazinedione. Al-Azhar Journal of Pharmaceutical Sciences, II, 33-45.

[18] El-Helby, A.-G.A., Ibrahim, M.K., Amin, M.A. and Ayyad, R.R.A. (2002) Synthesis and Anticonvulsant Activity of Phthalazindione Derivatives. Al-Azhar Journal of Pharmaceutical Sciences, 28, 22-35.

[19] Ibrahim, M.K., Abdel-Rahman, A.A., Ayyad, R.R.A., El-Adl, K., Elsherbeny, F. and Rashed, M. (2010) Design and Synthesis of Some Novel N-phthalimide Derivatives with Potential Anticonvulsant Activity. Al-Azhar Journal of Pharmaceutical Sciences, 42, 305-322.

[20] Alaa, A.-M., Abou-Zeid, L.A., El-Tahir, K.E.H., Ayyad, R.R., Magda, A.-A., and El-Azab, A.S. (2016) Synthesis, Anti-Inflammatory, Analgesic, COX-1/2 Inhibitory Activities and Molecular Docking Studies of Substituted 2-Mercapto-4(3H)-quinazolinones. European Journal of Medicinal Chemistry, 121, 410-421.

https://doi.org/10.1016/j.ejmech.2016.05.066

[21] Mohamed, M.A., Ayyad, R.R., Shawer, T.Z., Alaa, A.-M., et al. (2016) Synthesis and Antitumor Evaluation of Trimethoxyanilides Based on 4(3H)-quinazolinone Scaffolds. European Journal of Medicinal Chemistry, 112, 106-113. https://doi.org/10.1016/j.ejmech.2016.02.002

[22] Hall, J.H., Hall, E.S. and Wong, O.T. (1992) Cumulated Index Medicus. Anticancer Drug, 53, 55-62.

[23] Soje-Echaque, E. and Lim, R.K.S. (1962) Inflammation and Anti-Inflammatories. Spectrum, New York, USA. Journal of Pharmacology and Experimental Therapeutics, 49, 138-224.

[24] Eddy, N.B. and Leimbach, D. (1953) Synthetic Analgesics. II. Dithie-nylbutenyland dithienylbutylamines. Journal of Pharmacology and Experimental Therapeutics, 107, 385-393.

[25] Grever, M.R., Schepartz, S.A. and Chabner, B.A. (1992) The National Cancer Institute: Cancer Drug Discovery and Development Program. Seminars in Oncology, 19, 622-638.

[26] Boyd, M.R. and Paull, K.D. (1995) Some Practical Considerations and Applications of the National Cancer Institute in Vitro Anticancer Drug Discovery Screen. Drug Development Research, 34, 91-109.

[27] Mosmann, T. (1983) Rapid Colorimetric Assay for Cellular Growth and Survival: Application to Proliferation and Cytotoxicity Assays. The Journal of Immunological Methods, 65, 55-63.

[28] Dannhardt, G. and Kiefer, W. (2001) Cyclooxygenase Inhibitors-Current Status and Future Prospects. European Journal of Medicinal Chemistry, 36, 109-126. https://doi.org/10.1016/S0223-5234(01)01197-7

[29] Feagins, A.R., et al. (2020) Next Generation Rapid Diagnostic Tests for Meningitis Diagnosis. Journal of Infection, 81, 712-718.

https://doi.org/10.1016/j.jinf.2020.08.049

[30] Marnett, L.J., Rowlinson, S.W., Goodwin, D.C., Kalgutkar, A.S. and Lanzo, C.A. (1999) Arachidonic Acid Oxygenation by COX-1 and COX-2. Mechanisms of Catalysis and Inhibition. Journal of Biological Chemistry, 274, 22903-22906. https://doi.org/10.1074/jbc.274.33.22903 
[31] Picot, D., Loll, P.J. and Garavito, R.M. (1994) The X-Ray Crystal Structure of the Membrane Protein Prostaglandin H2 Synthase-1. Nature, 367, 243-249. https://doi.org/10.1038/367243a0

[32] Luong, C., Miller, A., Barnett, J., Chow, J., Ramesha, C. and Browner, M.F. (1996) Flexibility of the NSAID Binding Site in the Structure of Human Cyclooxygenase-2. Nature Structural Biology, 3, 927-933. https://doi.org/10.1038/nsb1196-927

[33] Kurumbail, R.G., Stevens, A.M., Gierse, J.K., McDonald, J.J., Stegeman, R.A., Pak, J.Y., Gildehaus, D., Miyashiro, J.M., Penning, T.D., Seibert, K., Isakson, P.C. and Stallings, W.C. (1996) Structural Basis for Selective Inhibition of Cyclooxygenase-2 by Anti-Inflammatory agents. Nature, 384, 644-648. https://doi.org/10.1038/384644a0

[34] Seibert, K., Zhang, Y., Leahy, K., Hauser, S., Masferrer, J., Perkins, W., Lee, L. and Isakson, P. (1996) Pharmacological and Biochemical Demonstration of the Role of Cyclooxygenase 2 in Inflammation and Pain. Nature, 91, 12013-12017.

https://doi.org/10.1073/pnas.91.25.12013

https://pubmed.ncbi.nlm.nih.gov/7991575/

[35] Savage, R. (2005) Cyclo-Oxygenase-2 Inhibitors: When Should They Be Used in the Elderly? Drugs \& Aging, 22, 185-200.

https://doi.org/10.2165/00002512-200522030-00001

[36] Thiemermann, C., Wu, C.C., Szabo, C., Perretti, M. and Vane, J.R. (1993) Role of Tumour Necrosis Factor in the Induction of Nitric Oxide Synthase in a Rat Model of Endotoxin Shock. British Journal of Pharmacology, 110, 177-182. https://doi.org/10.1111/j.1476-5381.1993.tb13789.x

[37] Halliwell, B. (1994) Free Radicals, Antioxidants, and Human Disease: Curiosity, Cause, or Consequence? The Lancet, 344, 721-724. https://doi.org/10.1016/S0140-6736(94)92211-X

[38] Griffith, O.W. and Stuehr, D.J. (1995) Nitric Oxide Synthases: Properties and Catalytic Mechanism. Annual Review of Physiology, 57, 707-734.

https://doi.org/10.1146/annurev.ph.57.030195.003423

[39] Hämäläinen, M., Nieminen, R., Vuorela, P., Heinonen, M. and Moilanen, E. (2007) Anti-Inflammatory Effects of Flavonoids: Genistein, Kaempferol, Quercetin, and Daidzein Inhibit STAT-1 and NF- $\mathrm{B}$ Activations, Whereas Flavone, Isorhamnetin, Naringenin, and Pelargonidin Inhibit only NF- $\kappa$ B Activation along with Their Inhibitory Effect on iNOS Expression and NO Production in Activated Macrophages. Mediators of Inflammation, 2007, Article ID: 45673.

https://doi.org/10.1155/2007/45673

[40] Soslow, R.A., Dannenberg, A.J., Rush, D., Woerner, B.M., Khan, K.N., Masferrer, J. and Koki, A.T. (2000) COX-2 Is Expressed in Human Pulmonary, Colonic, and Mammary Tumors. Cancer, 89, 2637-2645.

https://doi.org/10.1002/1097-0142(20001215)89:12<2637::AID-CNCR17>3.0.CO;2$\underline{\mathrm{B}}$

[41] Ermert, L., Dierkers, C. and Ermert, M. (2003) Immunohistochemical Expression of Cyclooxygenase Isoenzymes and Downstream Enzymes in Human Lung Tumors. Clinical Cancer Research, 9, 1604-1610.

[42] Koki, A.T. and Masferrer, J.L. (2002) Celecoxib: A Specific COX-2 Inhibitor with Anticancer Properties. Cancer Control, 9, 28-35. https://doi.org/10.1177/107327480200902S04

[43] Lirk, P., Hoffmann, G. and Rieder, J. (2002) Inducible Nitric Oxide Synthase-Time for Reappraisal. Current Drug Targets-Inflammation \& Allergy, 1, 89-108. 
https://doi.org/10.2174/1568010023344913

[44] Winter, C.A., Risky, E.A. and Nuss, G.W. (1962) Carrageenin-Induced Edema in Hind Paw of the Rat as an Assay for Antiinflammatory Drugs. Proceedings of the Society for Experimental Biology and Medicine, 111, 544-547.

https://doi.org/10.3181/00379727-111-27849

[45] Moda, T.L., Torres, L.G., Carrara, A.E. and Andricopulo, A.D. (2008) PK/DB: Database for Pharmacokinetic Properties and Predictive in Silico ADME Models. Bioinformatics, 24, 2270-2271.

[46] Joe, D., Zheng, O., Jeffery, T., Andrew, B., Yaron, T. and Jie, L. (2006) CASTp: Computed Atlas of Surface Topography of Proteins with Structural and Topographical Mapping of Functionally Annotated Residues. Nucleic Acids Research, 34, 116-118. https://doi.org/10.1093/nar/gkl282

[47] Bouaziz-Terrachet, S., Toumi-Maouche, A., Maouche, B. and Taïri-Kellou, S. (2010) Modeling the Binding Modes of Stilbene Analogs to Cyclooxygenase-2: A Molecular Docking Study. Journal of Molecular Modeling, 16, 1919-1929.

https://doi.org/10.1007/s00894-010-0679-7

[48] Marialuigia, F., Cristina, M., Fabio, L., Antonia, P., Simona, M., Mirko, P., Lorenza, S., Alessandra, A., Barbara, D.F., Letizia, G., Nazzareno, R. and Rosa, A. (2011) Selective Inhibition of iNOS by Benzyl- and Dibenzyl Derivatives of N-(3-Aminobenzyl)acetamidine. ChemMedChem, 6, 1203-1206. https://doi.org/10.1002/cmdc.201100125

[49] Thomas, J.L., Mack, V.L., Glow, J.A., Moshkelani, D., Terrell, J.R., Bucholtz, K.M. (2008) Structure/Function of the Inhibition of Human $3 \beta$-Hydroxysteroid Dehydrogenase Type 1 and Type 2 by Trilostane. The Journal of Steroid Biochemistry and Molecular Biology, 111, 66-73. https://doi.org/10.1016/j.jsbmb.2008.04.007 